U. S. Department of the Interior

U. S. Geological Survey

\title{
The Red Sea Basin Province: Sudr-Nubia(!) and Maqna(!) Petroleum Systems
}

\author{
by \\ Sandra J. Lindquist ${ }^{1}$
}

\section{Open-File Report 99-50-A}

This report is preliminary and has not been reviewed for conformity with the U.S. Geological Survey editorial standards or with the North American Stratigraphic Code. Any use of trade names is for descriptive purposes only and does not imply endorsement by the U.S. government.

${ }^{1}$ Consultant to U. S. Geological Survey, Denver, Colorado 


\title{
The Red Sea Basin Province: Sudr-Nubia(!) and Maqna(!) Petroleum Systems ${ }^{2}$
}

\author{
Sandra J. Lindquist, Consultant to \\ U.S. Geological Survey, Denver, CO \\ World Energy Project
}

October, 1998

\section{FOREWORD}

This report is a product of the World Energy Project of the U.S. Geological Survey, in which the world has been divided into 8 regions and 937 geologic provinces for purposes of assessment of global oil and gas resources (Klett and others, 1997). These provinces have been ranked according to the discovered petroleum volumes within each; highranking provinces (76 "priority" provinces exclusive of the U.S.) and others with varying types and degrees of intrigue (26 "boutique" provinces exclusive of the U.S.) were chosen for appraisal of oil and gas resources. The petroleum geology of these non-U.S. priority and boutique provinces are described in this series of reports. A detailed report containing the assessment results for all provinces will be available separately.

The Total Petroleum System concept is the basis for this assessment. A total petroleum system includes the essential elements and processes, as well as all genetically related hydrocarbons that occur in petroleum shows, seeps and accumulations (discovered and undiscovered), whose provenance is a pod or related pods of mature source rock (concept modified from Magoon and Dow, 1994). The minimum petroleum system is that portion of the total petroleum system for which the presence of essential elements and processes has been proved. The assessment unit is a mappable volume of rock within the total petroleum system, sufficiently homogeneous in terms of geology, exploration strategy and risk characteristics to constitute a single population with respect to criteria used for the chosen methodology of resource assessment. Assessment units are considered established if they contain more than 13 fields, frontier if they contain 1-13 fields and hypothetical if they contain no fields.

A unique, eight-digit numeric code identifies each assessment unit with respect to region, province, and petroleum system. The first digit is the region number, the next three digits the province number, the next two digits the total petroleum system number, and the final two digits the assessment unit number. The codes for the regions and provinces were established, listed and mapped in Klett and others, 1997.

\footnotetext{
${ }^{2}$ Sudr-Nubia(!) Total Petroleum System (\# 207101) - Gulf of Suez and northwestern Red Sea; Egypt; Red Sea Basin Province (2071); Middle East and North Africa (Region 2).

Maqna(!) Total Petroleum System (\#207102) - southern Gulf of Suez and Red Sea; Egypt, Sudan, Eritrea (Ethiopia), Yemen, and Saudi Arabia; Red Sea Basin Province (2071); Middle East and North Africa (Region 2).
} 
Figures in this report that show boundaries of total petroleum systems, assessment units, and pods of active source rock were compiled using geographic information system (GIS) software. Political boundaries and cartographic representations on these figures were taken with permission from ESRI (Environmental Systems Research Institute, Inc.) ArcWorld 1:3 million digital coverage. The boundaries have no political significance and are displayed for general reference only. Oil and gas field centerpoints shown on these figures are reproduced with permission from Petroconsultants, 1996. Also included as a figure is an events chart that shows the time of deposition of essential rock units; the time processes (such as trap formation) necessary for the accumulation of hydrocarbons; the critical moment in the petroleum system; and the preservation time. The format is that proposed by Magoon and Dow (1994).

\section{$\underline{A B S T R A C T}$}

The Sudr-Nubia(!) oil-prone total petroleum system dominates the densely explored Gulf of Suez part of the rifted Red Sea Basin Province. Upper Cretaceous to Eocene source rocks, primarily the Senonian Sudr Formation, are organic-rich, areally uniform marine carbonates that have generated known ultimate recoverable reserves exceeding $11 \mathrm{BBOE}$. The name Nubia is used for sandstone reservoirs with a wide range of poorly constrained, pre-rift geologic ages ranging from Early Paleozoic to Early Cretaceous. Syn- and postrift Tertiary reservoirs, especially the Kareem Formation, also contain significant reserves.

Partly overlapping Sudr-Nubia(!) is the areally larger and geochemically distinct, oil-andgas-prone Maqna(!) total petroleum system within the southern Gulf of Suez basin and the sparsely explored remaining Red Sea basin. Known ultimate recoverable reserves are 50-100 MMBOE and more than $900 \mathrm{MMBOE}$, respectively, in those areas. Both the source and reservoir rocks in this petroleum system are Tertiary, dominantly Miocene, in age. Maqna(!) has the greater potential for future resource development.

\section{INTRODUCTION}

As defined for this assessment, the Red Sea Basin Province geographically includes the rifted sedimentary basins under several bodies of water, plus their tectonically related adjacent coastal regions. In this report, the phrases "Gulf of Suez" and "Gulf of Aqaba" refer to the sedimentary basins at the northern end of the province underlying the bodies of water of the same names, plus the appropriate adjacent coastal areas. Similarly, "Red Sea" (without the word "Province") refers to the sedimentary basin beneath the Red Sea water column and its coastal region, exclusive of the Gulf of Suez and Gulf of Aqaba.

The 600,000-sq-km Red Sea Basin Province has two total petroleum systems, SudrNubia(!) (Egyptian nomenclature) and Maqna(!) (Saudi Arabian nomenclature), with $18,000 \mathrm{sq} \mathrm{km}$ of overlap along a 300-km distance in the southern Gulf of Suez and adjacent Red Sea (Figures 1 and 2, stratigraphy; Figures 3a-3c, maps). Sudr-Nubia(!) is densely explored, but Maqna(!) is not. Tertiary rifting and sea-floor spreading have resulted in sub-basins, with floors of tilted fault blocks, containing temporally and 
Figure 1. Pre-Rift Red Sea Stratigraphy (Precambrian to Oligocene).

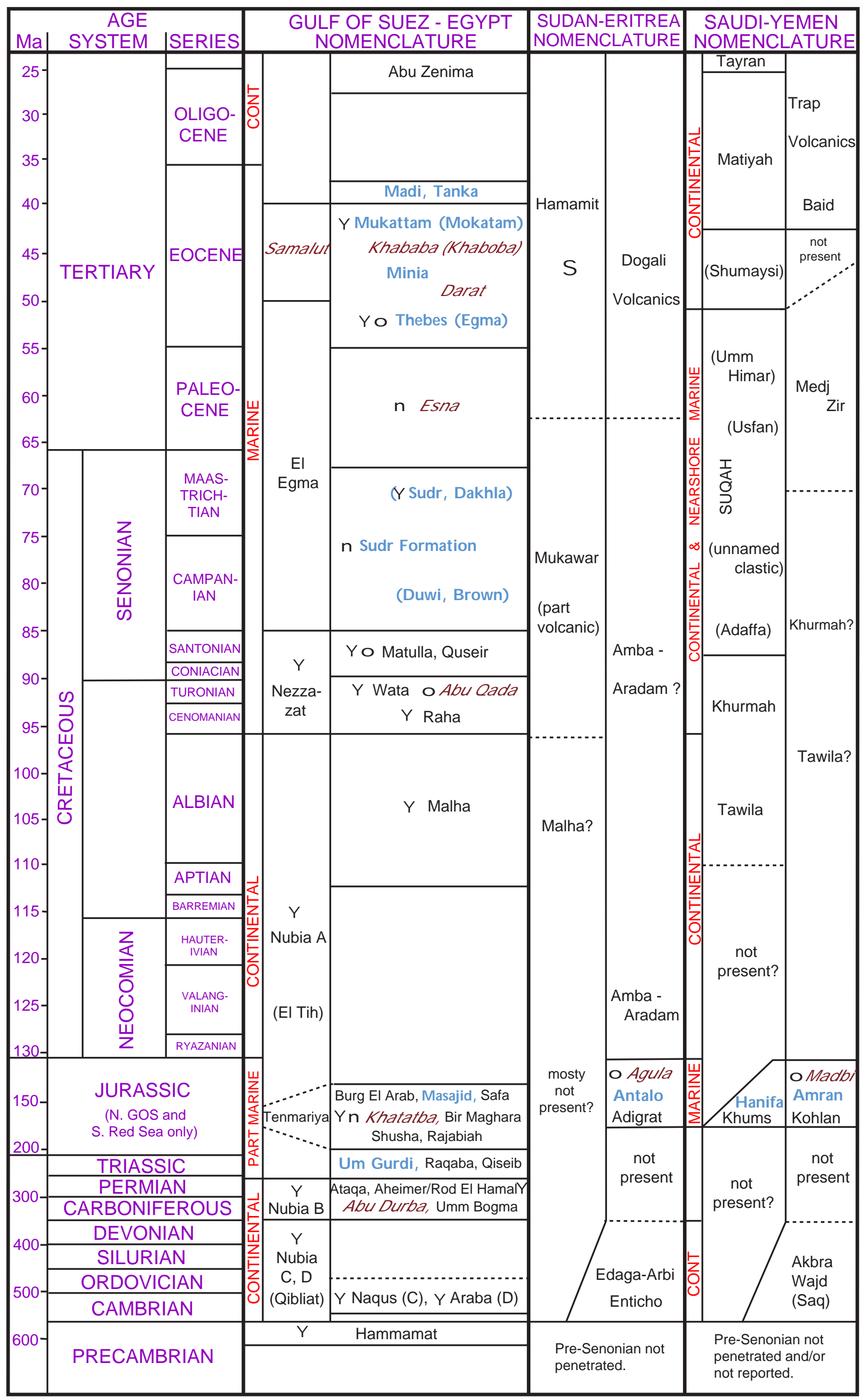

EXPLANATION: This chart is a compilation of stratigraphic nomenclature of the Red Sea region from many sources. It is not intended to be precise with respect to geologic age or correlation. CONT = continental. 
Figure 2. Syn- and Post-Rift Red Sea Stratigraphy (Oligocene to Recent)

\begin{tabular}{|c|c|c|c|c|c|c|c|c|c|c|c|c|c|c|c|}
\hline Mal & $\begin{array}{r}\text { AGE } \\
\text { SERIES }\end{array}$ & STAGE & $\begin{array}{l}\mathrm{Oth} \\
\mathrm{No}\end{array}$ & her & & $\begin{array}{r}\text { GULF C } \\
\text { NON }\end{array}$ & $\begin{array}{l}\text { DF SUEZ - EGYPT } \\
\text { MENCLATURE }\end{array}$ & $\begin{array}{l}\text { SUDA } \\
\text { NOME }\end{array}$ & $\begin{array}{l}-E R \\
\text { NCLA }\end{array}$ & $\begin{array}{l}\text { RITREA } \\
\text { ATURE }\end{array}$ & $\begin{array}{c}\text { Red Sea } \\
\text { N otes }\end{array}$ & & $\begin{array}{l}\text { SAUDI - } \\
\text { NOMENCI }\end{array}$ & $\begin{array}{l}\text { YEMEN } \\
\text { LATURE }\end{array}$ & \\
\hline $\begin{array}{l}0 \\
1 \\
0\end{array}$ & $\begin{array}{l}\text { HOLOCENE } \\
\text { PLEIST. }\end{array}$ & & † & 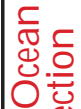 & & Shagara & & Shagara & 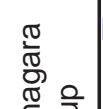 & $\begin{array}{l}\text { Dunishulo } \\
\text { (S seep) }\end{array}$ & $\begin{array}{l}\text { Begin } \\
\text { true }\end{array}$ & $\begin{array}{c}z \\
<\end{array}$ & Dunishub & Shagara & \\
\hline $3-1$ & & Piacenzian & $\notin$ & $\frac{1}{\sigma} 气$ & & & & & & & or & 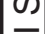 & & & \\
\hline 4. & PLIOCENE & Zanclian & $\frac{\overline{2}}{2}$ & 응 & & Wardan & & $\begin{array}{c}\mathrm{S} \\
\text { Wardan }\end{array}$ & $\begin{array}{l}\mathbb{4} \\
\end{array}$ & Desset & inting & - & Abbas & o Wardan & \\
\hline 6 & & Messinian & & & & & & $\mathrm{P}$ (dry gas) & & 0 & & & & & \\
\hline $\begin{array}{r}7 \\
8 \\
9 \\
10 \\
11 .\end{array}$ & & Tortonian & $\oplus$ & 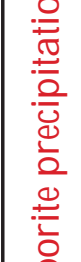 & $\begin{array}{l}0 \\
\widetilde{\sigma} \\
\widetilde{\sigma} \\
\widetilde{\sigma} \\
\Sigma \\
\omega\end{array}$ & $\begin{array}{c}\text { Yo Zeit } \\
\text { Yo } \\
\text { S. Gharib }\end{array}$ & Sabrut El Gamal & $\mid \begin{array}{c}1 \\
0 \\
0 \\
5 \\
\text { condensate } \\
0\end{array}$ & Digna & Amber & & 1 & $\begin{array}{c}\text { o } \\
\text { Mansiyah }\end{array}$ & $\begin{array}{c}\text { "Supra" } \\
\text { o Zeit } \\
\text { (Amber) } \\
\text { o } \\
\text { S.Gharib } \\
\end{array}$ & 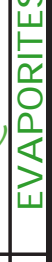 \\
\hline $\begin{array}{l}12 \\
13\end{array}$ & ш & Serravalian & 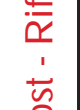 & 닐 & $\begin{array}{r}\widetilde{\sigma} \\
\widetilde{\sim}\end{array}$ & $\begin{array}{c}\text { Y O Belayim } \\
\text { (Alaqa, } \\
\text { Y Gemsa) }\end{array}$ & $\begin{array}{l}\text { Y o Haman Faraun, Feiran } \\
\text { Y o Sidri, Baba }\end{array}$ & $\begin{array}{r}\text { Abu } \\
\text { Tobana }\end{array}$ & $\begin{array}{l}\text { Imama } \\
\mathrm{n}, \mathrm{Kho}\end{array}$ & $\underset{\mathrm{Eit}}{\mathrm{O} Y}$ & & $\begin{array}{l}\varangle \\
z \\
0\end{array}$ & $\begin{array}{l}\text { Y n Kial } \\
\text { Umluj, } \\
\text { Dubaybah }\end{array}$ & S Halaib & $\varangle$ \\
\hline $\begin{array}{l}14 \\
15\end{array}$ & ए & I nabian & 0 & & & $\begin{array}{c}\text { Yo } \\
\text { Kareem }\end{array}$ & 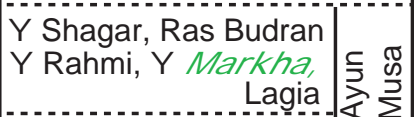 & & & సి & Begin & $\sum$ & $\begin{array}{l}\text { Y n Jabal Kibrit } \\
\text { Umluj, } \\
\text { Wadi Waqb } \\
\end{array}$ & $\begin{array}{c}\text { o } \\
\text { "Infra" }\end{array}$ & 厅 \\
\hline $16+$ & $\frac{0}{\Sigma}$ & Langnirán & & $\frac{5}{0}$ & $\overline{\widetilde{\tau}}$ & $\begin{array}{l}\text { Y n } \\
\text { U. Rudeis }\end{array}$ & $\begin{array}{l}\text { Mreir, Y Ayun } \\
\text { Y Asl, Safra } \\
\text { Y Hawara, Y Yusr }\end{array}$ & $\begin{array}{l}5 \\
0 \\
0 \\
0\end{array}$ & 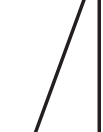 & $\begin{array}{l}\text { ब0 } \\
\text { I }\end{array}$ & $\begin{array}{l}\text { Aqaba } \\
\text { wrenching }\end{array}$ & 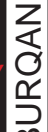 & Subayti & Zeiydia & 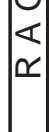 \\
\hline $\begin{array}{l}18 \\
19\end{array}$ & & Burdigalian & Rift & 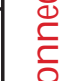 & 암. & Y n L. Rudeis & Mheiherrat, Bakr & ס & & & & $\begin{array}{l}\infty \\
0\end{array}$ & Nutaysh & 0 & \\
\hline $\begin{array}{l}20 \\
21 \\
22 \\
23 \\
24\end{array}$ & & Aquitanian & 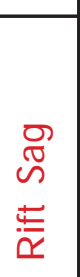 & 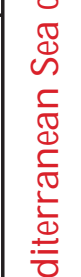 & 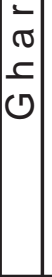 & $\begin{array}{c}\mathrm{Y} \\
\text { Nukhul } \\
\text { (Abu Gerfan) }\end{array}$ & $\begin{array}{c}\text { Ghara / Y October / } \\
\text { Y Gharamul } \\
\text { Khoshera } \\
\text { Nebwi, Sudr } \\
\text { Ras Matarma } \\
\text { Y Shoab Ali }\end{array}$ & $: \frac{\varpi}{\varepsilon}$ & $\begin{array}{l} \\
\sigma \\
0 \\
\circ \\
0\end{array}$ & & & $\begin{array}{l}z \\
< \\
\alpha \\
z \\
z\end{array}$ & $\begin{array}{l}\text { Musayr } \\
\text { Yanbu } \\
\text { Al Wajh }\end{array}$ & 0 ? & $\begin{array}{l}-a \\
\frac{a}{\alpha} \\
\end{array}$ \\
\hline $\begin{array}{l}26 \\
27 \\
28\end{array}$ & OLIGOCENE & Chattian & & $\Sigma$ & & Abu Zenima & & $\begin{array}{l}E \\
\tilde{T} \\
I\end{array}$ & & & $\begin{array}{l}\text { Begin } \\
\text { rifting }\end{array}$ & $\vdash$ & $\begin{array}{c}\text { Jizan } \\
\text { volcanics } \\
\text { Matiyah }\end{array}$ & & \\
\hline
\end{tabular}

\section{EXPLANATION:}

o Potential source rock

n Effective source rock
Y Oil production

$\mathrm{S}$ Oil show
Mostly evaporite Mostly carbonate
This chart is a compilation of stratigraphic nomenclature and geologic events ( $N$ otes) of the Red Sea region from many sources. It is not intended to be precise with respect to geologic age or geologic correlation. 


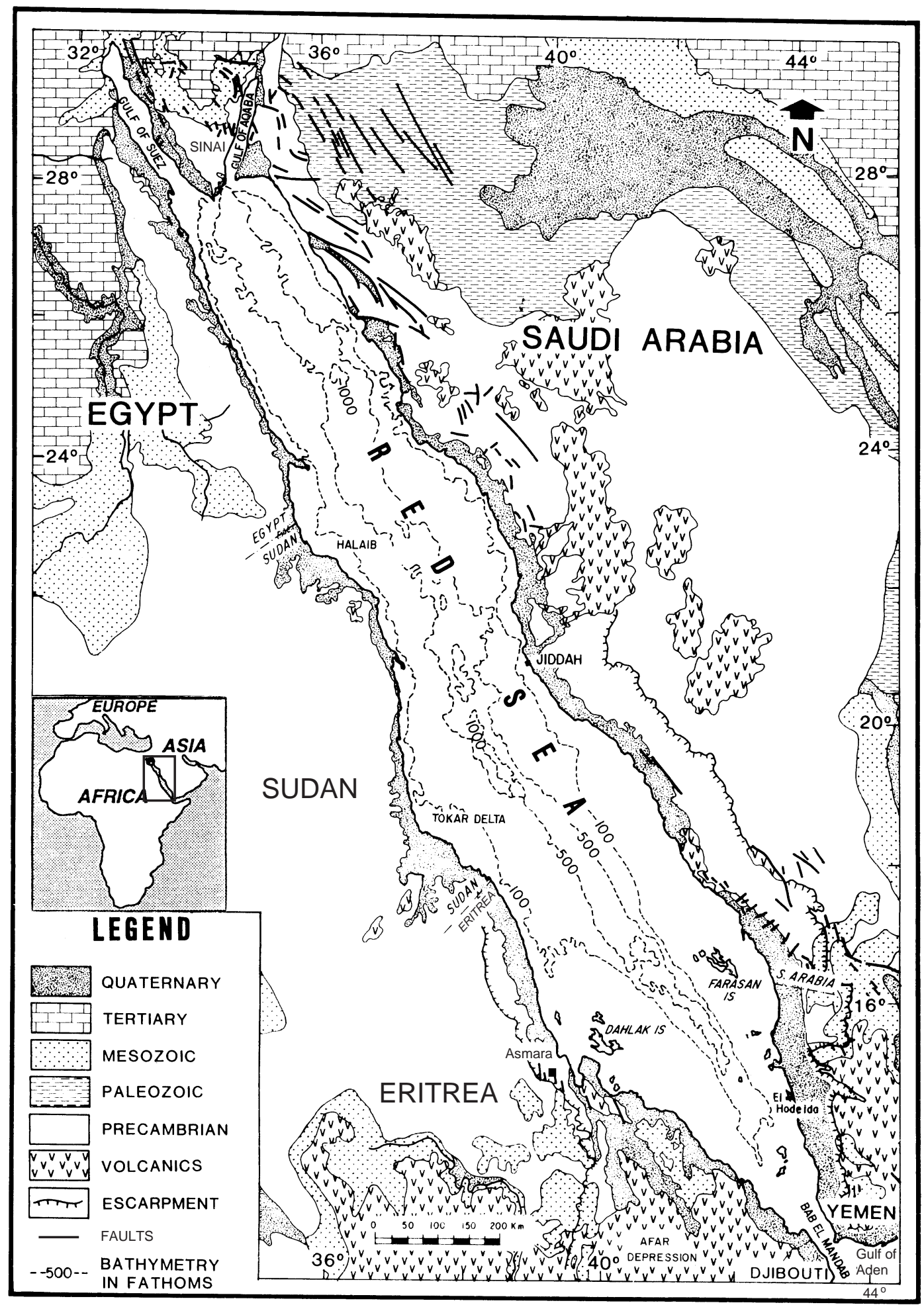

Figure 3a. Index map of the Red Sea region showing generalized geology and discussed locations (after Mitchell and others, 1992). 


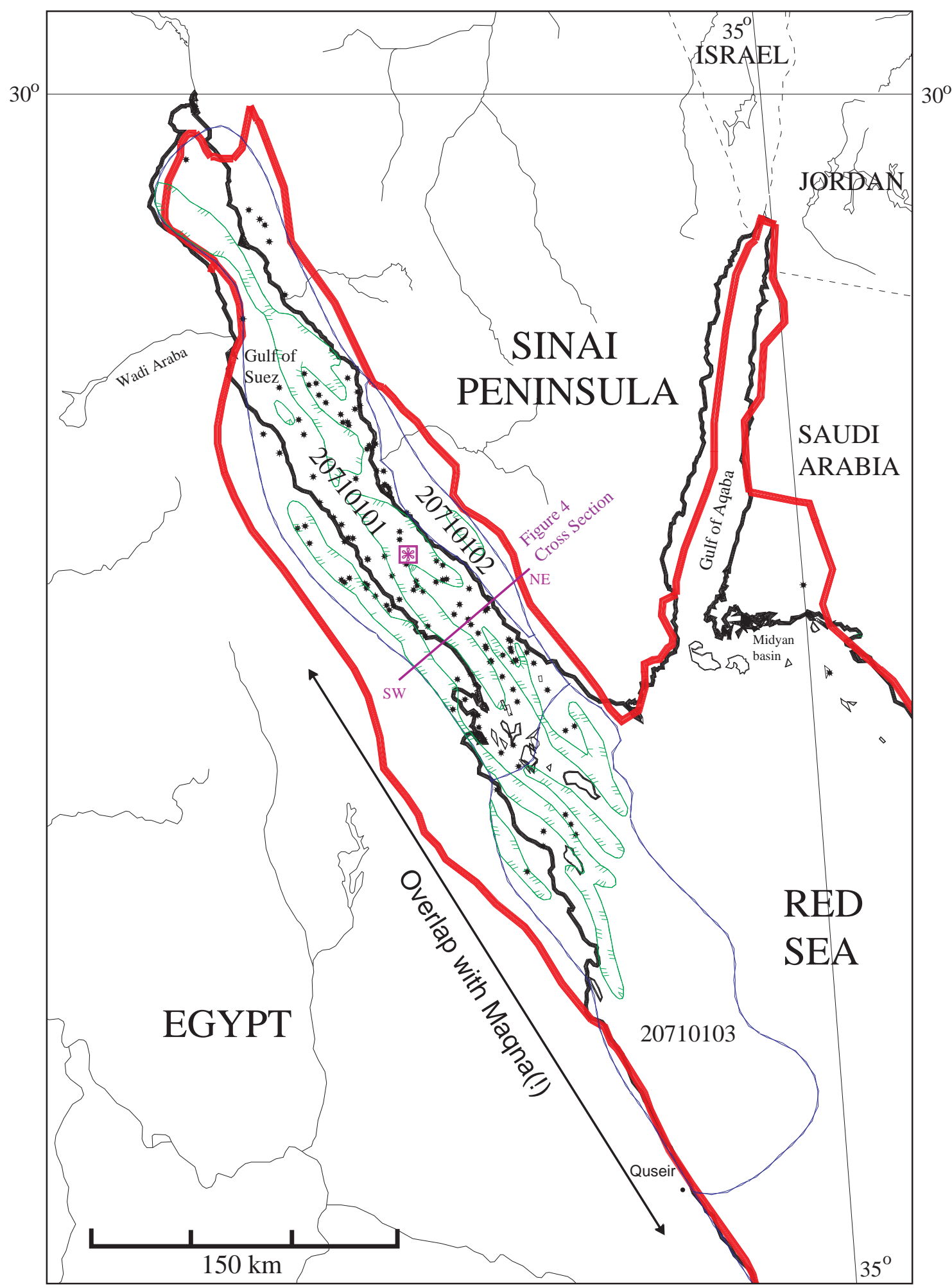

Figure 3b. Index map of the Gulf of Suez region showing extent of Sudr-Nubia(!) total petroleum system (207101), Red Sea Province (2071). The 3 assessment units are discussed in the text.

\section{EXPLANATION}

- Rivers

- Shore

- Red SeaProvince boundary

-- Country Boundary

* Field Centerpoints
橉 Burial history chart location (Fig. 6a)

$20710101 \_$Assessment unit code and boundary

Minimum petroleum system includes just fields and active source rock.

Total petroleum system includes all three assessment units.

Boundary of pod of active source rocks Tics indicate side of their presence 


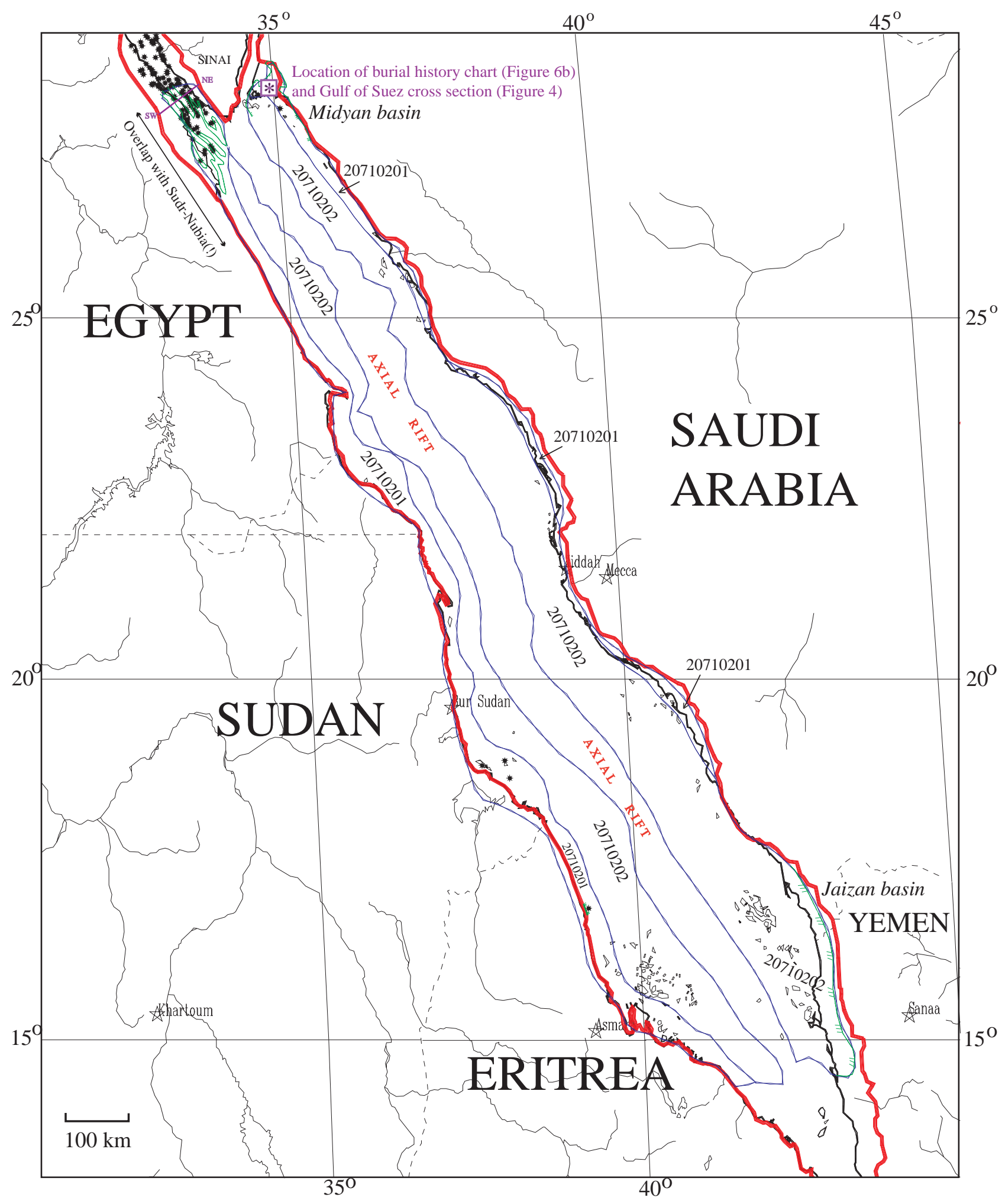

Figure 3c. Index map of the Red Sea showing extent of the Maqna(!) total petroleum system (207102), Red Sea Province (2071). The 2 assessment units are discussed in the text.

\section{EXPLANATION}

- Rivers

- Shore

- Red Sea Province boundary

- Country Boundary

橉 Burial history chart location (Fig 6b)

* Field centerpoints 20710101 Assessment units, code and boundary

Total petroleum system includes all assessment units (presence on side of tic marks) 
regionally variable thermal gradients. Areas of active source rock are discontinuous and are located within grabens or on horsts that have high thermal gradients. Oil migrated along dip slopes and faults within the last several to ten million years in both petroleum systems. In the Red Sea Basin Province, $95 \%$ of all wells drilled and discoveries made are within the 25,000-sq-km Gulf of Suez.

Sudr-Nubia(!) has an approximate 31,000-sq-km area, $73 \%$ offshore, covering the Gulf of Suez and extending another $100 \mathrm{~km}$ southeast into the northwestern Red Sea. Source rocks are Upper Cretaceous to Eocene marine carbonates that produce a gammaceranerich oil trapped in reservoir rocks ranging in age from Paleozoic to Tertiary. Maqna(!) is over 400,000 sq km in area. Middle Miocene shale source rocks produce oleanane-rich oils and wet gases trapped primarily in Miocene reservoirs. Eighty-nine percent of Maqna(!) is offshore. Not included within the assessed part of Maqna(!) is the Red Sea axial spreading center, which is less than $5 \mathrm{~m} . \mathrm{y}$. old and has an average width ranging from 45 to $75 \mathrm{~km}$ and a length of $1880 \mathrm{~km}$. Other potential source rocks exist in Jurassic marine rocks of the northernmost Gulf of Suez and the southernmost Red Sea.

The Red Sea area has significant representation in international scientific literature, with volumes of study, often resulting from regional symposia, periodically published. Primary sources of published information include private and nationalized industry, academia, regional governmental agencies, the Deep Sea Drilling Project and the United Nations Development Program / World Bank. References listed in this report include a limited selection of those most recent and most pertinent to this document. Not all are specifically cited in the text. Petroconsultants (1996), a global data base of exploration and production, forms the basis for most quantitative discussion. The stratigraphic equivalents charts are composited from many references to approximately equate the range of stratigraphic nomenclature in use. They are not intended to be precise with respect to absolute geologic age.

\section{PROVINCE GEOLOGY}

\section{Province Boundary and Geographic Setting}

The Red Sea Basin Province includes offshore and adjacent onshore areas, from the northern Gulf of Suez ( $350 \mathrm{~km}$ by $70 \mathrm{~km}$ ) and Gulf of Aqaba (185 km by $25 \mathrm{~km}$ ) southeastward along the Red Sea to the Gulf of Aden in the Indian Ocean. The province is a Tertiary cratonic rift south of Egypt's Sinai Peninsula between northeastern Africa and the Arabian Peninsula (Figure 3a). Northwest-southeast length of the province is $2300 \mathrm{~km}$, with a width to $400 \mathrm{~km}$. The Gulf of Suez is an abandoned rift basin with less than 100-meter water depths. The Gulf of Aqaba is a younger, rapidly subsiding wrench basin with maximum water depth of 1850 meters. The remaining Red Sea Basin Province is an active rift where sea-floor spreading has occurred for the last 5 m.y. and where water depths locally exceed 2300 meters in the axial region. 


\section{Political Entities}

Within or directly bordering the Red Sea Basin Province are Egypt, Sudan, Eritrea (formerly part of Ethiopia), Djibouti, Yemen, Saudi Arabia, Jordan, and Israel. Saudi Arabia is a member of the Organization of Petroleum Exporting Countries (OPEC). Both Saudi Arabia and Egypt are members of the Organization of Arab Petroleum Exporting Countries (OAPEC). Border disputes exist between Saudi Arabia and Yemen and between Egypt and Sudan. Sudan has been chronically plagued by civil war and, in 1996, was sanctioned by the United Nations for sponsoring terrorism. A civil war in Yemen ended in 1994. Eritrea and Ethiopia have had recent conflicts.

\section{Geologic Setting}

The Red Sea Basin Province originated as an Oligocene continental rift impacted by leftlateral wrenching. Rift location and borders are defined by crustal weaknesses created more than $500 \mathrm{Ma}$ - including the late Proterozoic to early Paleozoic cratonization of the Arabian-Nubian shield, its suturing to the African continent, and subsequent supercontinent breakup. Those events resulted in the juxtaposition of structurally and compositionally different basement terranes and the establishment of major fault systems. Periodic Paleozoic and Mesozoic subsidence focused around the present-day southern Mediterranean (Tethyan) margin was complemented by local and regional uplifts (e.g., late Paleozoic Hercynian orogeny, late Cretaceous to early Tertiary Tethyan closure and Syrian arc formation).

Parts of the Paleozoic and Mesozoic rock record were either eroded or not deposited, particularly in the central Red Sea area, and various structural fabrics were imparted to the region. When present and preserved, pre-rift stratigraphy is more marine in character northward through the northern part of the province, and only Cretaceous seas ever transgressed south of the Aqaba-Suez-Red Sea triple junction. Tethys shorelines to the east failed to completely transgress the Arabian Peninsula westward except in late Jurassic and earliest Cretaceous time, when marine environments covered the southern quarter of the Red Sea, south from the Farasan and Dahlak islands.

Oligocene continental rifting began with subsidence, extension and normal faulting, associated with the episodic and segmented movement of the Arabian peninsula away from Africa. Magmatic expansion resulted in igneous emplacements, and isostatic compensation caused the rift shoulders to undergo uplift and local erosion into the rapidly subsiding and tilting block-faulted basins (Figure 4). Syn-rift depositional conditions (thus, facies and lithologies) varied laterally. Later thermal re-equilibration resulted in reduction of subsidence, regional basin uplift and further rotation of faulted blocks. Postrift evaporite deposition was extensive until Pliocene when open marine conditions were established.

Rifting was sequentially younger northward, and tens to hundreds of meters of faultblock relief were common. Total extension in the Red Sea decreased northward into the Gulf of Suez. Gulf of Suez rifting essentially ceased (early-middle Miocene, 18 - $14 \mathrm{Ma}$ ) (Figure 2) when continental separation became more oblique because of the dominant 


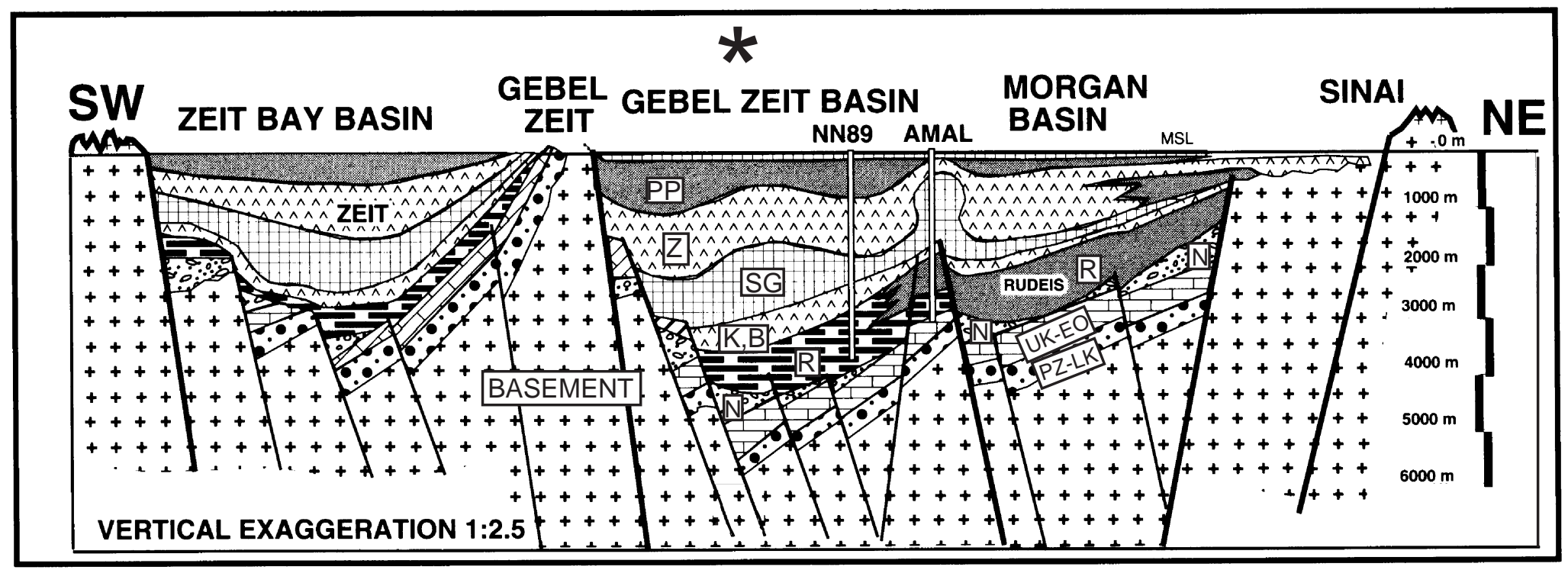

Figure 4. Generalized structural cross section in the central Gulf of Suez approximates the critical moment for both Sudr-Nubia(!) and Maqna(!) total petroleum systems (after Schutz, 1994). The deepest part of the Gebel Zeit Basin $\left(^{*}\right)$ is a comparable location (although 500-600 m shallower) for the burial history chart in Figure 6a. Depending on thermal gradient (generally hotter southward and on rift margins and horst blocks in the Gulf of Suez basin), the Tertiary source rocks (N, R, K, B) enter the oil window and the Cretaceous source rocks (UKEO) become gas mature. Thus, thermal maturity lines on this cross section would be slightly concave and reflective of basement structure, with $\mathrm{R}$ (Rudeis) being thermally mature in the basins illustrated. Cross section location is shown on Figures $3 b$ and $3 c$.

LEGEND: PZ-LK = Paleozoic to Lower Cretaceous Nubia (reservoir rock); UK-EO = Upper Cretaceous to Eocene pre-rift carbonate (source rock); N, R, K, and B = syn- and post-rift Nukhul, Rudeis, Kareem and Belayim formations (sources, reservoirs, seals and overburden); SG = South Gharib salt (seal and overburden); $\mathrm{Z}=$ Zeit (seals and overburden); and PP = Plio-Pleistocene (overburden). 
movement on the left-lateral transform fault that extends through the Gulf of Aqaba northeastward to the Dead Sea. Gulf of Suez fault blocks are generally smaller and more highly rotated southward, concurrent with increased basin extension. Subsidence continued at reduced rates in the southern Gulf of Suez, but Pliocene uplift in the northernmost part caused limited basin inversion. Fault blocks in the northern and southern thirds of the Gulf of Suez dip dominantly southwestward, whereas those in the center third tilt mostly northeastward.

Extensive wrench faulting resulted in the development of transtensional and transpressional areas in the Gulf of Aqaba and along the northern (northwestern Saudi Arabia) and western (Egypt and Sudan) margins of the Red Sea, trending southward toward the East African rift system. Thus, crustal profiles across the Red Sea rift are asymmetric. The steep Egyptian-Sudanese margin has a narrow shelf delineated by wrench faults and ancient suture zones, with pull-apart basins floored by oceanic crust. The eastern margin and southern area are floored by attenuated continental crust. A continuous marine connection from the Gulf of Suez to the Indian Ocean was first established $5 \mathrm{Ma}$ (Pliocene) with the advent of sea-floor spreading in the southern part of the province (Figure 2). Contemporaneous local salt movement throughout the region ranged from the creation of massive domes and walls to total removal.

\section{Exploration History}

\section{Gulf of Suez (120+ fields or discovery wells)}

Gemsa field along the southwestern Gulf of Suez coast was discovered in 1869 and first produced in 1910, followed by Hurghada field in 1913. Five more fields were discovered between the two world wars when well completion rates were several-to-ten per year. After World War II, activity spread to the eastern coast, and annual well completions increased to several dozen by 1973. During the early to mid 1980s, as many as 133 wells were completed in one year, but 1990s levels declined to an annual range of 50 to 60. The 1900+ wells in the Gulf of Suez basin define more than 120 fields, with nearly half currently listed as one-well discoveries (Petroconsultants, 1996). Thirty fields include ten or more producing wells, and fewer than ten fields are abandoned.

\section{Western Side of Red Sea (4 fields)}

The Egyptian Red Sea south of the Gulf of Suez has 22 dry holes, six with hydrocarbon shows. One well was drilled in 1916, five in the late 1930s and 1940s, 14 between 1976 and 1985, and two in 1994. The Sudanese Halaib area with one 1982 penetration is in a disputed border zone with Egypt. Three dry holes were drilled along the central Sudanese Red Sea coast in 1962, and Sudan's southern Tokar Delta has three unproduced, one-well gas fields resulting from 10 attempts between 1961 and 1996. (Durwara 2 was discovered in 1963, and Suakin 1 and Bashayer 1A were both discovered in 1976. Suakin has associated condensate, and the one offset (1996) is dry.) Eritrea has an offshore, one-well gas field not yet produced. Eleven wells were drilled in the salt- 
cored Dahlak Islands from 1938-1940. Deeper wells (one hydrocarbon show) tested eight Eritrean offshore locations from 1966-1977.

\section{Eastern Side of Red Sea (2 fields)}

No wells have been drilled within the Gulf of Aqaba, but two fields were discovered in an adjacent Saudi Arabian transpressional basin (Midyan basin) - offshore Barqan field in 1969 and onshore Midyan field in 1992. Both fields tested gas, condensate and oil, but neither has produced. The Saudi Arabian coastal area has more than 30 penetrations (1967-1994) over the 1500-km distance from the Gulf of Aqaba to the Yemen border. Data and locations are published for nine wells, six of which are near Yemen. Seven shallow 1930s tests were drilled near oil seeps in the salt-cored Farasan Islands. Thirteen Yemeni wells - several with oil or gas shows - have tested (1961-1996) the Red Sea Basin Province.

\section{PETROLEUM OCCURRENCE}

Surface oil seeps in the Red Sea Basin Province occur in two major areas (Mitchell and others, 1992; Beydoun, 1989). In the northeastern Red Sea, bordering Saudi Arabia and south of the Gulf of Aqaba, coastal seeps probably are related to active faulting associated with the Aqaba transform system. The southern Red Sea has seeps around the salt-cored Farasan and Dahlak Islands, along most of the Eritrean coast (southwestern Red Sea), and along the southern Saudi Arabian and Yemeni coasts (southeastern Red Sea), including several salt domes (e.g., Jaizan and Salif).

More than 1900 wells in the Gulf of Suez delineate 60 fields plus an equal number of one-well reported discoveries, for a total of 120 fields. The remaining province area has fewer than 100 well penetrations with three confirmed productive areas (offshore Tokar Delta of Sudan, offshore Eritrea, offshore and onshore northwestern Saudi Arabia). Exploratory wells are distributed over the entire Red Sea area, and most had oil or gas shows.

Hydrocarbon accumulations in the Red Sea Basin Province likely exceed 22 BBOE in place, with ultimate expected recoveries of 11.75 BBOE (Petroconsultants, 1996). Fiftyfive percent of that ultimate volume has been produced. Of the overall ultimate volumes, approximately $13.5 \%$ is gas $(9.53 \mathrm{TCF})$ and $2.5 \%$ is condensate. Just $8-9 \%$ of the gas and condensate has been produced.

Known Sudr-Nubia(!) accumulations (Figure 3b) are expected to ultimately recover 10.75 BBOE, with 6.42 BBOE already produced (Petroconsultants, 1996). Sudr-Nubia(!) field sizes in MMBOE are characterized by means of 101 (arithmetic) and 8 (geometric), a median of 9.5 and a mode of 5 (Figure 5, Table 1). API gravities average 28, but range from 12 to 58. Production GORs are typically less than 10,000 cfg/bo. Known Maqna(!) accumulations (Figure 3c) will ultimately recover just under $1 \mathrm{BBOE}$, with $24 \mathrm{MMBOE}$ having been produced from the southern Gulf of Suez. Maqna(!) field sizes in MMBOE have means of 58 (arithmetic) and 7 (geometric), a median of 5.8 and a mode of 10 
Figure 5. Histogram showing distribution of petroleum field sizes in the Red Sea Province for Sudr-Nubia(!) and Maqna(!) total petroleum systems.

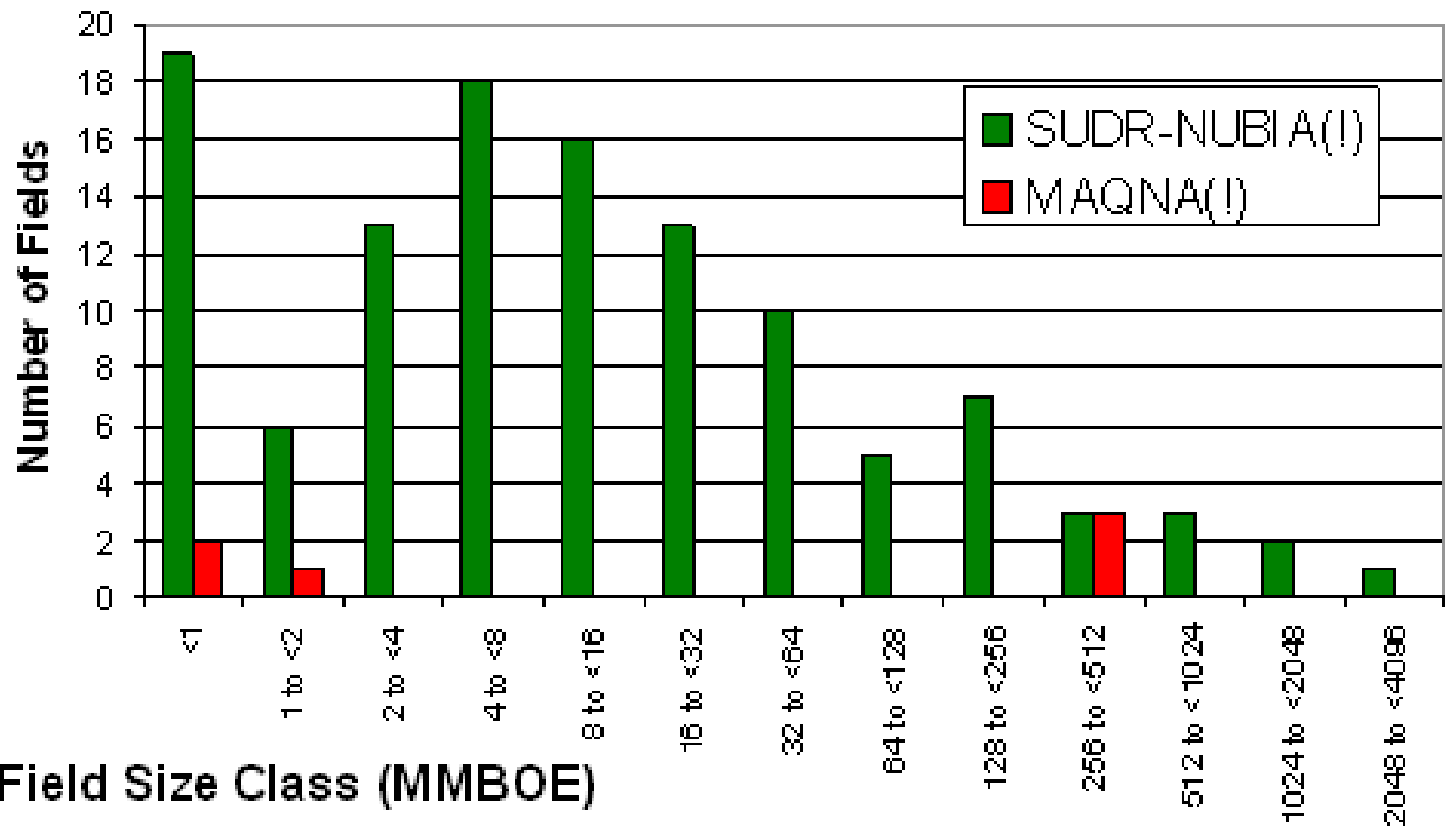

(ultimate recover able reserves, Petroconsultants, 1996) 
Table 1. Fields and reserve statistics of the Sudr-Nubia(!) and Maqna(!) total petroleum systems, Red Sea Province.

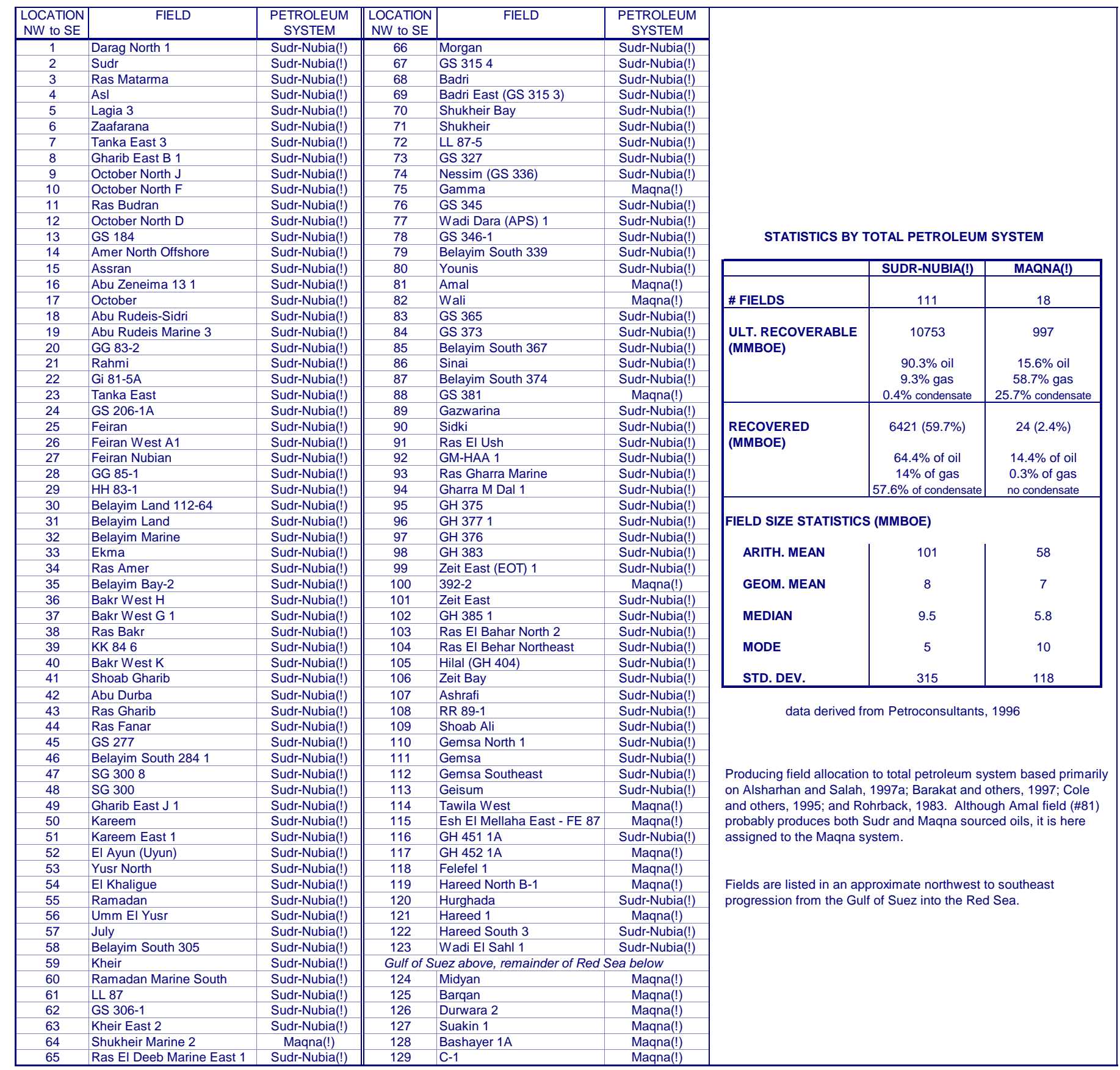


(Figure 5, Table 1). API gravities range from 20 to 58, but average around 40.

Production GORs to date are less than 5,000 cfg/bo.

Total reserve distribution by reservoir rock is shown in Table 2 for the Gulf of Suez (dominantly the Sudr-Nubia(!) total petroleum system), with proportions reported by Salah and Alsharhan (1997) contrasted with proportions derived from the Petroconsultants data base (Petroconsultants, 1996). Half or more of all reserves are in syn- and post-rift Tertiary rocks, particularly the Kareem Formation. Somewhat fewer reserves are in pre-rift reservoirs, particularly Nubia equivalents. Petroconsultants' data identifies Nubia sandstones as being the dominant reservoir rocks. The Maqna(!) petroleum system has its largest known accumulations outside the Gulf of Suez where approximate Kareem equivalents trap most discovered hydrocarbons.

Hydrocarbon migration paths range from rather simple cross-fault juxtapositions of mature source and reservoir (e.g., Ramadan field, Abdine and others, 1992) to what must be more tortuous cross-fault migrations combined with upward migrations through fault blocks to a seal (e.g., October field, Lelek and others, 1992).

\section{SOURCE ROCK}

\section{Campanian Sudr (Brown/Duwi) Source Rock of the Gulf of Suez}

The major oil-prone source rock in the Gulf of Suez is the pre-rift, Upper Cretaceous (Senonian) marine Sudr Formation, particularly the Campanian Brown/Duwi Member, a uniform, organic-rich, uraniferous limestone. Late Cretaceous seas may have transgressed as far south as central Sudan and central Saudi Arabia (Schandelmeier and others, 1997; Mitchell and others, 1992; Beydoun, 1989). Brown/Duwi phosphatic shales crop out from as far north as Wadi Araba in the northern Gulf of Suez to Quseir on the Egyptian Red Sea (Figure 3b). Brown/Duwi age equivalents in the Midyan basin, at the Gulf of Aqaba junction with the eastern Red Sea coast, are largely terrigenous (Hughes and Filatoff, 1994), and other Midyan subsurface pre-rift rocks also have poor source quality (Cole and others, 1995).

In the Gulf of Suez, Brown/Duwi thicknesses are 25-70 meters. Total organic carbon content averages $2.6 \mathrm{wt} \%$ (Lelek and others, 1992), but values as high as $21 \mathrm{wt} \%$ have been measured in some Egyptian phosphate mines (Abdine and others, 1992). Kerogen is typically type II, with $\mathrm{H} / \mathrm{C}$ ranging from 1.1 to 1.4 and $\mathrm{O} / \mathrm{C}<0.1$ (Alsharhan and Salah, 1997a). The Brown/Duwi source rock is thermally mature to oil (and locally gas) in numerous offshore and several onshore grabens of the Gulf of Suez. Oil expulsion from a typical Gulf of Suez source pod probably began 10-8 Ma (Abdine and others, 1992; Shahin, 1988) during the time of extensive evaporite deposition (Figures 6a and 7a).

Oils from the Sudr Formation are identified by characteristics commonly associated with carbonate source rocks and saline depositional environments - relatively high sulfur content $(>1 \%)$; pristane/phytane ratios of generally $<1$; the presence of the biomarker gammacerane; the presence of $\mathrm{C}_{27}$ and $\mathrm{C}_{30}$ steranes; significant tricyclic, tetracyclic, and 


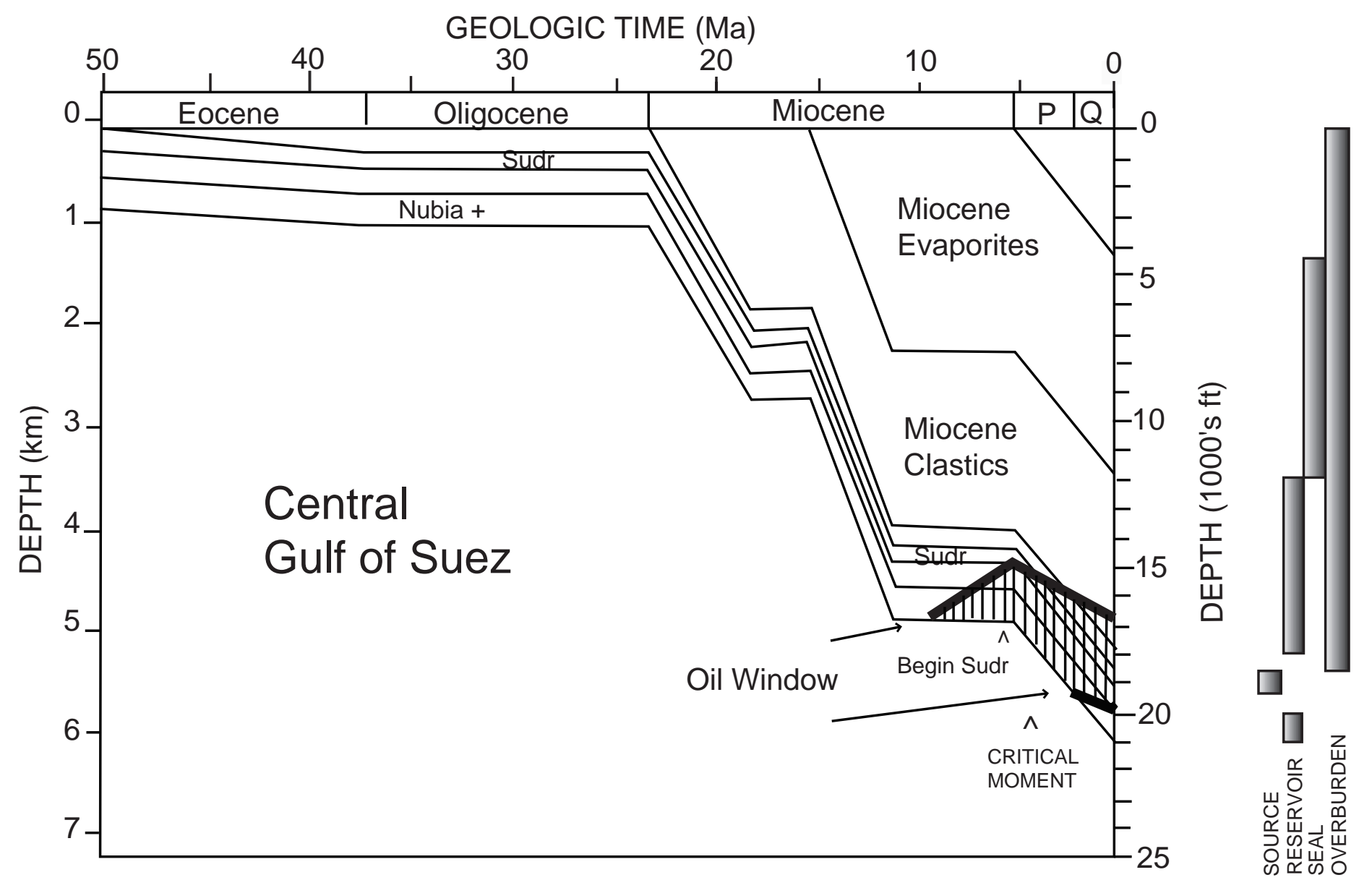

Figure 6a. Burial history chart for the Sudr-Nubia(!) total petroleum system (207101), based on the Ramadan field area (central Gulf of Suez) illustrating oil generation from Upper Cretaceous carbonates beginning $6 \mathrm{Ma}$. The critical moment at this location is defined at $4 \mathrm{Ma}$ when the Sudr Formation was well within the oil window. The location of this burial history chart is shown on Figure $3 \mathrm{~b}$ and is 500-600 meters deeper than the deepest part of the Gebel Zeit basin shown in Figure 4. After Abdine and others, 1992. 


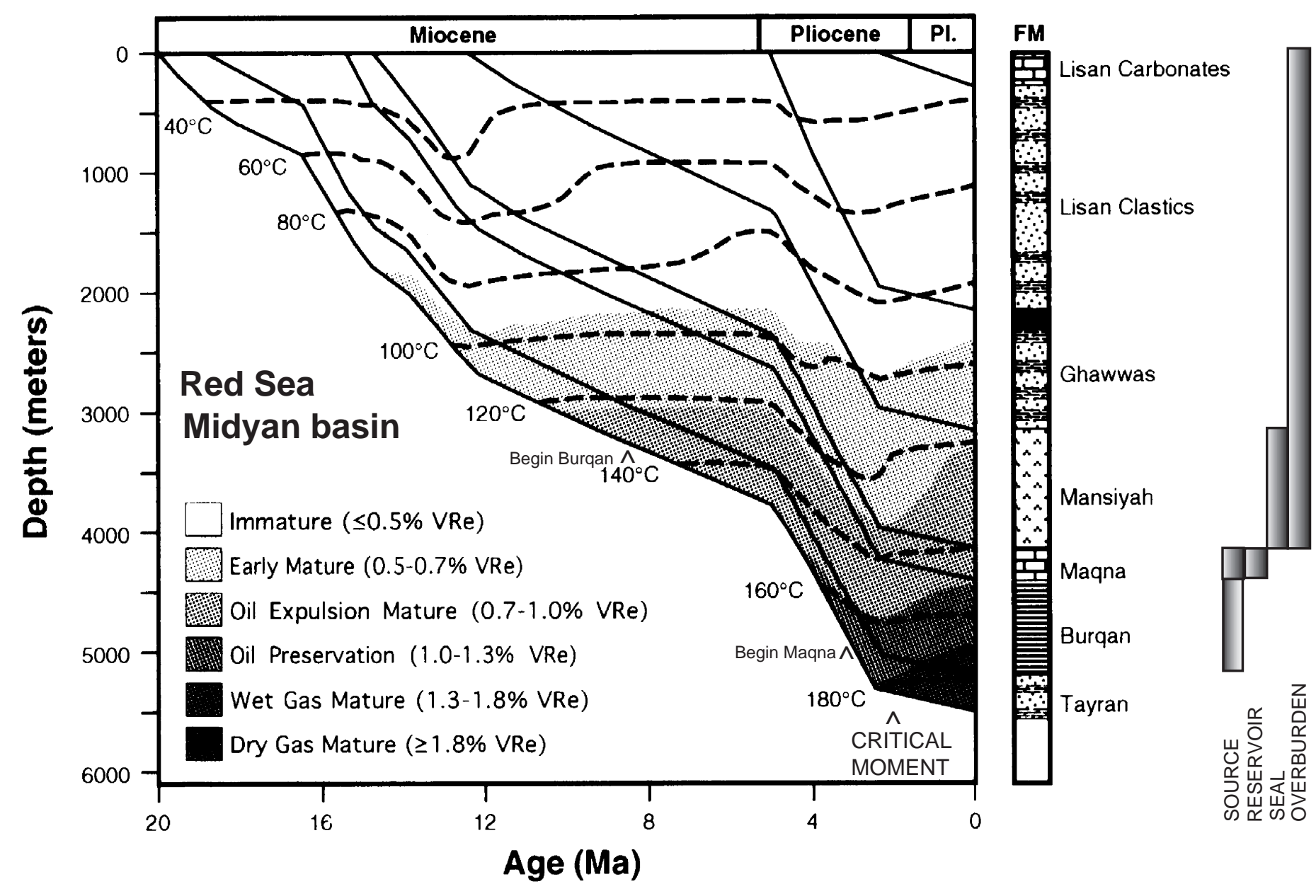

Figure 6b. Burial history chart for the Maqna(!) total petroleum system (207102), based on the Midyan basin of the Red Sea (northwest Saudi Arabia) illustrating oil expulsion from the Miocene basal Burqan Formation beginning $9 \mathrm{Ma}$ and from the Maqna Formation at $3 \mathrm{Ma}$. The critical moment at this location is defined at $2 \mathrm{Ma}$ when the Maqna expulsion began and the Burqan Formation entered the wet-gas window. See Figure $3 \mathrm{c}$ for location of burial history chart. After Cole and others, 1995. 
Figure 7a. Events chart for the Sudr-Nubia(!) total petroleum system (207101), Gulf of Suez, Egypt, Red Sea Province (2071). Explanation of formation abbreviations: $N E Z$ = Nezzazat, $N=$ Nukhul, $R=$ Rudeis, K=Kareem, $B=B e l a y i m, S G=S o u t h$ Gharib, Z=Zeit.

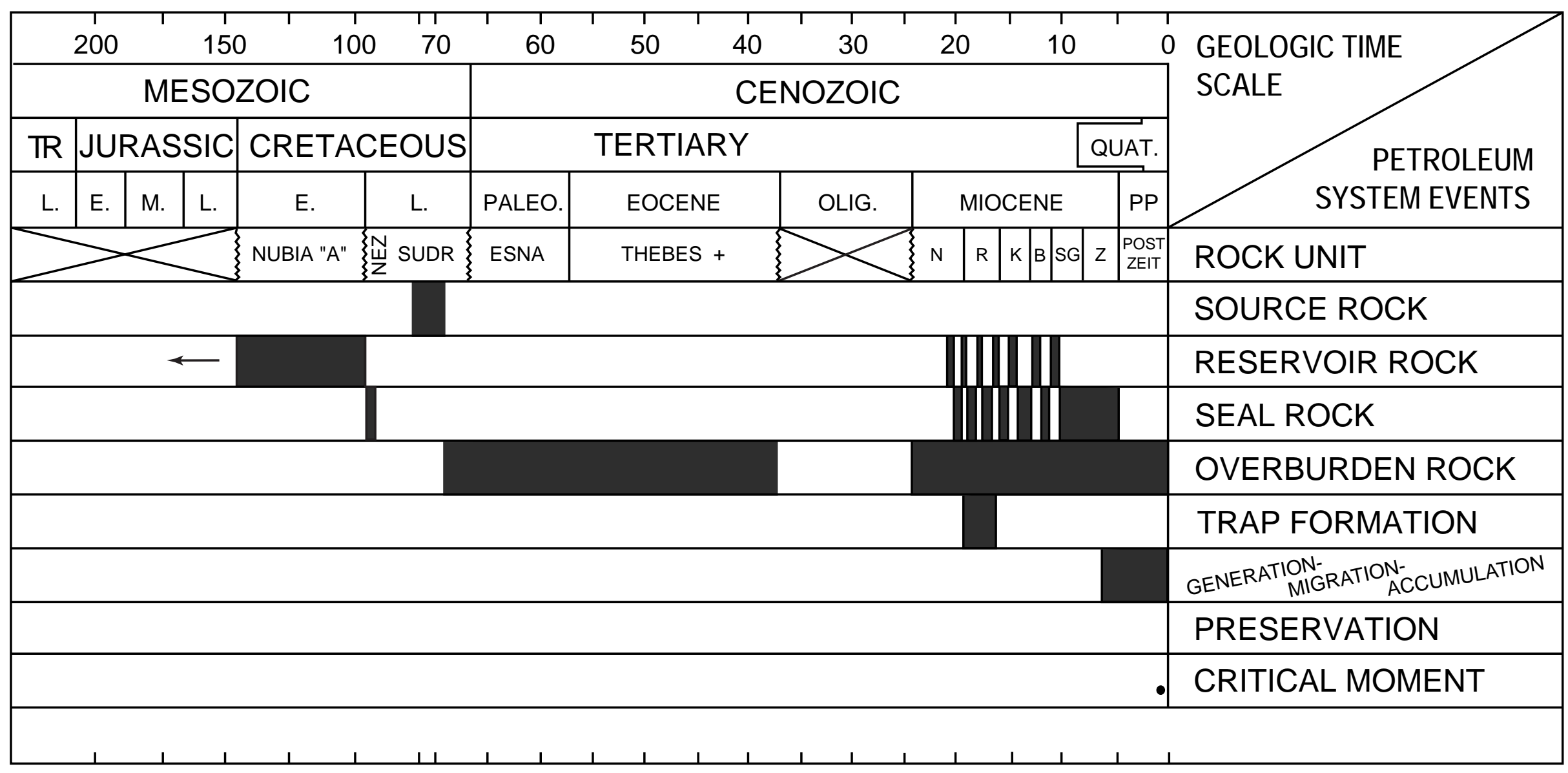

Sudr-Nubia(!) Events Chart 
Figure 7b. Events chart for Maqna(!) total petroleum system (207102), southern Gulf of Suez and entire Red Sea, Red Sea Province (2071). Explanation of formation abbreviations: NEZ=Nezzazat, $N=$ Nukhul, R=Rudeis, K=Kareem, $\mathrm{B}=$ Belayim, SG=South Gharib, Z=Zeit. Maqna is the age equivalent of Miocene K (Kareem) and B (Belayim).

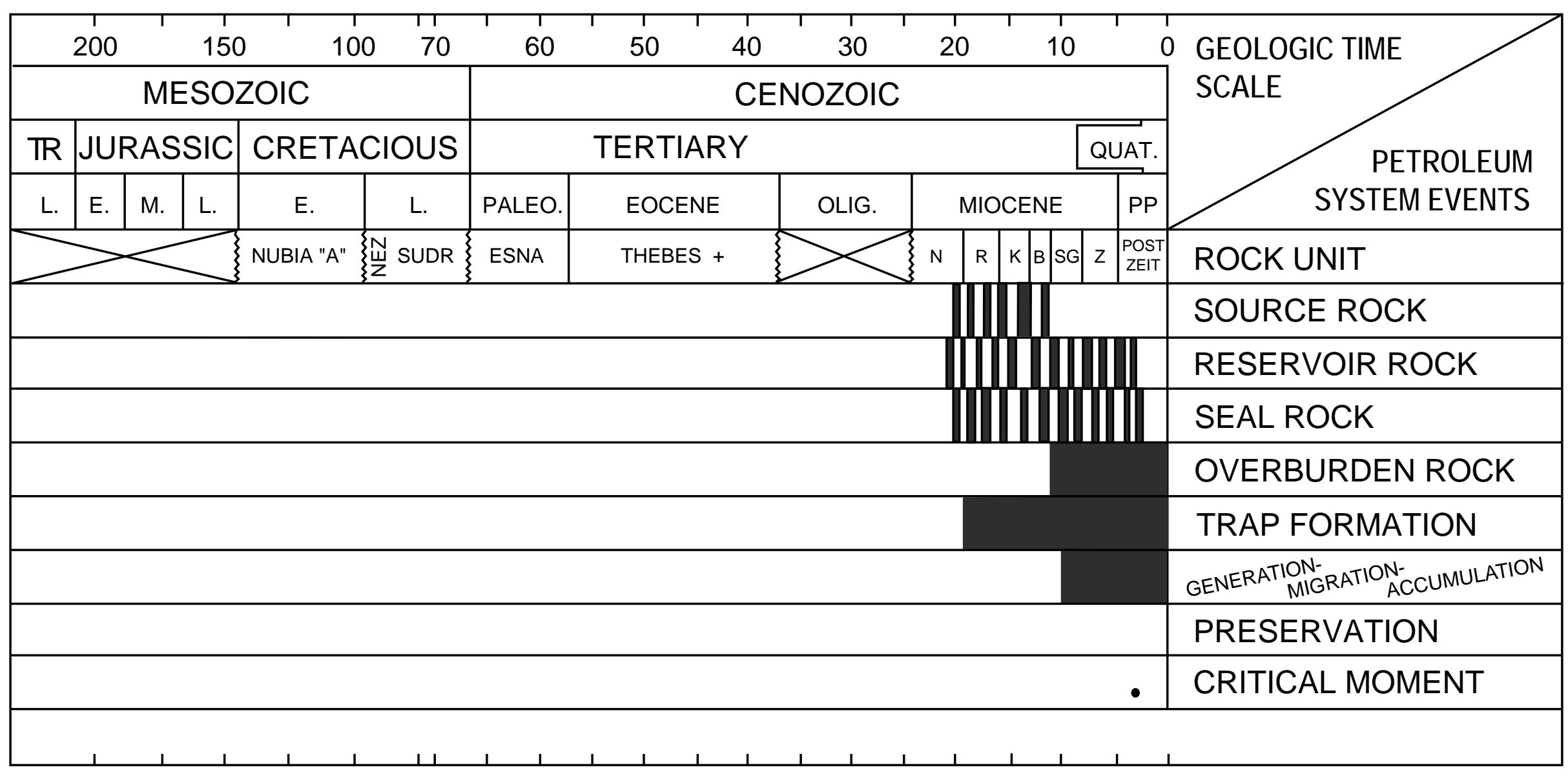

Maqna(!) Events Chart 
pentacylcic terpanes; and high $\mathrm{C}_{35} / \mathrm{C}_{34}$ (Barakat and others, 1997). These oils are also typically low in wax content and isotopically light $\left(\delta^{13} \mathrm{C}<-26\right.$ in aromatics and saturates), with relatively low $\mathrm{C}_{29}$, carbon preference index $(\mathrm{CPI})<1$, and a nickel/vanadium ratio <1 (Alsharhan and Salah, 1997a). These types of oils have been reported from as far south as Hurghada field at the mouth of the Gulf (Alsharhan and Salah, 1997a) to as far north as Ras Sudr field 280 km northwest (Rohrback, 1983).

\section{Middle Miocene Maqna Source Rock of the Red Sea and Southern Gulf of Suez}

Higher thermal gradients result in Miocene strata being thermally mature in the southern Gulf of Suez (Figures 6b and 7b). Syn-rift and post-rift Miocene source rocks were deposited in a variety of settings with limited lateral extents, resulting in variable kerogen type but an overall more terrigenous nature than Upper Cretaceous counterparts. Pods of potential Miocene source rock are expected to exist everywhere within the Red Sea Basin Province except for the youngest axial areas of both the Red Sea rift and the Gulf of Aqaba wrench system. The probable dominant source rock strata for this Tertiary petroleum system are in the Maqna Formation (Saudi Arabian nomenclature, Figure 2).

Source rocks as young as middle Miocene (Belayim) are mature in the deep Gemsa trough of the southwestern Gulf of Suez and in the Midyan basin of the northeastern Red Sea of Saudi Arabia (Alsharhan and Salah, 1997a). Lower Miocene (Rudeis) source intervals are mature in most grabens and some horsts at the mouth of the Gulf of Suez. Rudeis equivalents in the Midyan basin are at a wet-gas thermal-maturity stage.

Lower to middle Miocene source rocks at the southern end of the Gulf of Suez are type II to type III kerogen with hydrogen indices (HI) ranging from 100 to $700 \mathrm{mg} \mathrm{HC/g}$ TOC (gas prone to oil prone), total organic carbon content (TOC) commonly 1-4 wt \% and hydrocarbon yields $\left(S_{2}\right)$ of 4-9 kg/ton (Alsharhan and Salah, 1997a). Data from farther south on the western shore of the Red Sea also confirm mixed oil-and-gas potential with yields of 6,000-28,000 ppm (Barnard and others, 1992). Equivalent source rocks of offshore Sudan range from poor to good in quality, with TOC to $1.9 \mathrm{wt} \%$, HI reaching $200 \mathrm{mg} \mathrm{HC} / \mathrm{g}$ TOC (gas potential), and thicknesses of 11-75 meters (Bunter and Abdel Magid, 1989a, b).

In the Saudi Arabian Midyan basin (north, near the Gulf of Aqaba) and Jaizan basin (south, near the Yemen border), the middle Miocene Maqna Formation is a good oil source with TOC averaging 1-2 wt \% (maximum $14 \mathrm{wt} \%$ ), HI averaging 200-300 mg $\mathrm{HC} / \mathrm{g}$ TOC (maximum near 700), and hydrocarbon $\mathrm{S}_{2}$ yields averaging 2-6 mg HC/g rock (maximum 85) (Cole and others, 1995). Twenty-meter Maqna thicknesses are confirmed at Midyan - likely the source rock of the discovered black oil - but just 2-meter thicknesses were observed at Jaizan. The older Burqan and Tayran formations are tens of meters thick and regional in extent, but more gas prone with HI less than 200, TOC averaging $1.3 \mathrm{wt} \%$ or less, and $\mathrm{S}_{2}$ yields of $<3 \mathrm{mg} \mathrm{HC} / \mathrm{g}$ rock. The Burqan Formation is reported as the likely source for wet to dry gases tested at Jaizan. Oldest Miocene source rocks expelled oil from 11-10 Ma, whereas younger Maqna sources have been expelling from $5 \mathrm{Ma}$ (Jaizan) to $2 \mathrm{Ma}$ (Midyan) (Figures 6b and 7b). 
Oils from Miocene shales are identified by characteristics associated with more terrigenous kerogens and, thus, contrast with the previous Cretaceous Sudr oil descriptions. Sulfur content is low and generally $<1 \%$, wax high, pristane/phytane $>1$, $\mathrm{CPI}>1$, nickel/vanadium $=2, \mathrm{C}_{29}$ high, carbon isotopes heavier $\left(\delta^{13} \mathrm{C}>-26\right)$, and oleanane is the dominant biomarker instead of gammacerane (Barakat and others, 1997; Alsharhan and Salah, 1997a). Gamma field, near giant Morgan field and $110 \mathrm{~km}$ north of the Gulf of Suez junction with the Red Sea, is the northernmost Gulf of Suez field with production attributed to Miocene source rock (Barakat and others, 1997). Cole and others (1995) distinguish among potential Miocene source rocks at Midyan and Jaizan with analyses of tricyclics, hopanes, steranes and carbon isotopes. Miocene source rocks probably thicken appreciably in local depocenters not yet tested.

\section{Other Source Rocks}

Upper Miocene (salt and post-salt) and Pliocene strata have source-rock potential in the Red Sea, perhaps also including the youngest axial areas of both the Red Sea rift and the Gulf of Aqaba. Individual beds are rich (TOC approaching $30 \mathrm{wt} \%$ but averaging 1-4 wt $\%$ ) and prolifically oil prone (HI to $700, \mathrm{~S}_{2}$ yields as high as $144 \mathrm{mg} \mathrm{HC/g}$ rock), but are thin where penetrated in the Red Sea and of unknown lateral extents (Cole and others, 1995; Barnard and others, 1992; Beydoun and Sikander, 1992; Bunter and Abdel Magid, 1989a, b). Hotter wells of the southern Red Sea Basin Province are thermally mature for oil at Upper Miocene to Pliocene level, and oil seeps around the southern islands probably originated from those horizons (Mitchell and others, 1992).

Jurassic marine source rock with mixed oil-and-gas potential is mature in the northernmost Gulf of Suez. Shahin (1997) cited unspecified carbon isotope and biomarker data to attribute 1.2 BBOIP potential (0.112 BBO proven recoverable) from a 700-sq-km area of Jurassic Khataba shale that generated and expelled oil from 20-10 Ma into four northern Gulf of Suez fields. Other Jurassic source rocks (Agula, Madbi) could be preserved in fault blocks of the southern Red Sea margin along the Eritrean and Yemeni coasts and on the southernmost Red Sea central platform at moderate depths south of the salt basins (salt basin location discussed under "Assessment Units"). They now might be overmature near the coasts, but possibly not on the central platform, which is cooler because sea-floor spreading is offset westward from the platform - via a transform fault - into the onshore Afar depression (Figure 3a).

Other Upper Cretaceous to Eocene carbonates and shales in the Gulf of Suez (Abu Qada, Matulla, Esna, Thebes, Khababa) are claimed as identifiable or nominated as potential contributing source rocks in the Gulf of Suez and are at maturity levels similar to the Brown/Duwi Limestone. Shahin (1997) attributed 8.4 BBOIP potential, with 1.6 BBO proven recoverable in October field (north central Gulf of Suez) and the surrounding area, to Matulla sources in the northern Gulf of Suez. 


\section{OVERBURDEN ROCK}

\section{Thickness}

All post-Cretaceous rocks comprise Sudr-Nubia(!) overburden in the Gulf of Suez (Figures 6a and 7a). Pre-rift Paleocene and Eocene marine carbonates and shales, also potential source rocks, are several hundred to 500 meters thick and are overlain by a synand post-rift section of many lithologies and depositional facies ranging to 4000 meters in thickness. Evaporite lithologies can constitute several thousand meters of overburden. Some deeper grabens in the Gulf of Suez contain as much as 7000 meters thickness of rock above the pre-Miocene section (Patton and others, 1994). A burial history chart (Figure 6a) from the central Gulf of Suez near Ramadan field shows the Sudr Formation, currently at $5.5 \mathrm{~km}(18,000 \mathrm{ft})$ depth, generating oil $6 \mathrm{Ma}$ when it was at a $4.6-\mathrm{km}$ $(15,000 \mathrm{ft})$ depth.

The Maqna(!) total petroleum system is represented by a burial history curve from the Midyan basin in northwestern Saudi Arabia (Figure 6b). Overburden is restricted to middle Miocene and younger siliciclastics, evaporites and carbonates (Figure 7b). Oil expulsion began here at a depth of $3 \mathrm{~km}, 8 \mathrm{Ma}$ for the basal gas-prone Burqan shale and 3 Ma for the oil-prone Maqna carbonate source rocks. Less overburden is required for oil generation outside the Gulf of Suez where thermal gradients are higher. Oil maturity windows as shallow as 1000 meters are documented in the western Red Sea (Barnard and others, 1992).

\section{Thermal Gradient}

Thermal gradients in the Gulf of Suez basin range from $27^{\circ}$ to $46^{\circ} \mathrm{C} / \mathrm{km}\left(1.5^{\circ}\right.$ to $>2.5^{\circ}$ $\mathrm{F} / 100 \mathrm{ft}$ ), higher to the south and at rift margins and lower in deeper grabens (Alsharhan and Salah, 1997a; Schutz, 1994). Such trends and irregularities in thermal gradient are explained by heterogeneities in the crust causing hot spots and by laterally exposed basement increasing the horizontal component of heat flow.

Throughout the remaining Red Sea, thermal gradients and heat flow increase nonuniformly southward and from the basin margins inward toward the axial rift. An anomalously hot area is in the Tokar Delta of southern Sudan (Figure 3a), trending onshore southward toward the Danakil rift near Asmara, Eritrea. Another high thermal anomaly is in a Red Sea coastal well of south central Saudi Arabia. Deep Sea Drilling Project boreholes have registered axial Red Sea thermal gradients at least as high as $219^{\circ}$ $\mathrm{C} / \mathrm{km}\left(12^{\circ} \mathrm{F} / 100 \mathrm{ft}\right)$, and the highest thermal gradient recorded in a southern Red Sea oil and gas test is $76^{\circ} \mathrm{C} / \mathrm{km}\left(4.2^{\circ} \mathrm{F} / 100 \mathrm{ft}\right)$. Coastal Red Sea basin locations likely had higher geothermal gradients in the past when closer to the spreading center, whereas Gulf of Suez thermal gradients are probably highest now (Feinstein and others, 1996). Regional and temporal thermal variability and the block-faulted nature of the province results in a pod-like distribution of mature source rock with different stratigraphic horizons potentially mature in different areas. 


\section{TRAP STYLE OF OIL AND GAS FIELDS}

\section{Known Traps and Their Timing}

In Gulf of Suez producing fields, most traps are described as "tilted fault blocks," "faulted," or "structural" (Petroconsultants, 1996). Reservoirs within the fields have additional stratigraphic complexity, especially Tertiary syn-rift and post-rift strata, with varying lithologies and depositional facies ranging from carbonate build-ups and deep submarine clastics to terrigenous clastics (Figure 4).

Recoverable reserves in the Gulf of Suez are widely distributed stratigraphically (Table 2). Upper Cretaceous to Eocene carbonate source rocks (Figures 1 and 2) were deposited uniformly over a large area during tectonic stability, as was the Paleozoic to Cretaceous Nubia Formation, the dominant pre-rift sandstone reservoir. Trap and local seal formation occurred just prior to generation of substantial hydrocarbons (Figures 6 and 7). Deposition of the regional evaporitic seal was in progress or complete at the time of oil expulsion.

Gulf of Suez rifting peaked at "Mid-Rudeis" time, $18 \mathrm{Ma}$, and most pre-rift fault-block traps were thus formed, although reduced subsidence and lesser block rotation continue locally to the present. Younger Miocene reservoirs were deposited during the next 6 or 7 m.y. with depositional processes and facies distribution impacted by local topography in fault-bounded depocenters. As regional evaporites were being deposited, basinal source rocks were maturing, and expulsion of oil was occurring by $8 \mathrm{Ma}$. Deeper or hotter subbasins could have experienced Sudr expulsion as early as 12 or 14 Ma and would be mature for gas now.

Hydrocarbon generation from potential Jurassic source rocks also likely occurred after fault-block traps formed, particularly because rifting began first in the southern Red Sea. Shahin (1997) suggested that Jurassic sources in the northernmost Gulf of Suez expelled petroleum from 20-10 Ma. Although hotter at the southern end of the Red Sea, Jurassic source rock might be similarly mature because of lesser burial depth.

Younger Miocene source rock matured more recently in the southern Gulf of Suez, except in hotter areas where Miocene expulsion is nearly coeval with Cretaceous expulsion farther north. Most Red Sea thermal modeling from south of the Gulf of Suez shows Miocene expulsion to have begun at various times, but largely coeval with Cretaceous expulsion in the Gulf of Suez. Expulsion from youngest Pliocene potential sources in the southern Red Sea is current (Cole and others, 1995; Alsharhan and Salah, 1997a; Savoyat and others, 1989). Red Sea halokinesis occurred simultaneously during late stages of salt deposition because of the instability created by sea-floor spreading and continued subsidence. Salt-related structures are mostly less than $10 \mathrm{~m}$.y. old. 


\section{Undiscovered Traps}

Undiscovered Gulf of Suez traps for either the Sudr-Nubia(!) or Maqna(!) total petroleum systems are likely to be subtle block-faulted structures with stratigraphic complexity (e.g., Tertiary drapes, pinchouts and facies changes) - more difficult to delineate and less prolific than the more predictable and extensive Nubia reservoirs. Reserves might also be discovered in smaller, fault-sealed compartments within and adjacent to existing fields and associated with the limited salt diapirism at the southern end of the Gulf of Suez. Sudr-charged traps similar to those in the Gulf of Suez are expected in the sparsely drilled northwestern Red Sea along the Egyptian coast south to where organic-rich Brown/Duwi phosphates were found onshore near Quseir.

For the major part of the Maqna(!) total petroleum system outside the Gulf of Suez, similar block-faulted trap styles likely are present around both margins of the Red Sea basin. Seaward of the coastal margins, syn- and post-rift salt-related structures and stratigraphic traps are expected.

Traps in the Red Sea are also likely to preserve hydrocarbons from younger Miocene and Pliocene source rocks where thermal gradients are high. South of the Farasan and Dahlak Islands, potential source rocks in Jurassic marine shales might also charge coastal blockfaulted structural traps. Details concerning the quality and distribution of reservoir and source rock for the Red Sea are summarized by Mitchell and others (1992).

\section{$\underline{\text { RESERVOIR ROCK }}$}

Pre-rift reservoir rocks of the Gulf of Suez contain volumes of ultimate recoverable reserves comparable to syn- and post-rift counterparts, but the post-rift formations have better reservoir properties (Table 2). Overall, pre-rift formations average $18 \%$ porosity and 200 millidarcies (geometric) permeability. Syn- and post-rift reservoirs average $21 \%$ porosity and 450 millidarcies (geometric) permeability. Table 2 compares allocation proportions derived from Petroconsultants (1996) with those reported by Salah and Alsharhan (1997). The latter allocate a larger percentage of reserves to syn- and post-rift reservoirs. Gulf of Suez reservoirs primarily produce Sudr-generated oils and from all stratigraphic horizons.

Pre-rift sandstones, shales, and minimal carbonates (all collectively called Nubia and equivalents, Figure 1) were deposited during cratonic stability in continental to shallow marine environments covering most of the present-day Red Sea region. The Nubia Formation ranges in age from Early Paleozoic to Early Cretaceous and is preserved in grabens throughout the Gulf of Suez and on the Red Sea margins. Preserved gross thicknesses exceed 1000 meters $(3000 \mathrm{ft})$ with significant lateral continuity. Alsharhan and Salah (1997b) report Nubia net-pay thicknesses in the Gulf of Suez of 30-450 meters, porosities of 10-29\%, permeabilities of 70-850 millidarcies, and known recovery factors of $15-60 \%$. They estimate that Nubia reservoirs contain $19 \%$ of all Gulf of Suez production. 
Table 2. Percentage distribution of ultimate recoverable reserves by reservoir rock in the Gulf of Suez. Percentages not in parentheses are based on Petroconsultants (1996). Those from Salah and Alsharhan (1997) are shown in italics and parentheses. F information is derived from Petroconsultants (1996).

\begin{tabular}{|c|c|c|c|}
\hline $\begin{array}{l}\text { Reservoir } \\
\text { Rock }\end{array}$ & $\begin{array}{c}\text { Ultimate } \\
\text { Recoverable } \\
(\%)\end{array}$ & $\begin{array}{c}\text { Average } \\
\text { Porosity (\%) }\end{array}$ & $\begin{array}{c}\text { Average } \\
\text { Permeability (mD) } \\
\text { geom (arith) }\end{array}$ \\
\hline $\begin{array}{c}\text { POST- AND SYN-RIFT } \\
\text { (post-Oligocene) } \\
\text { Shukeir (Pliocene) } \\
\text { Zeit (Upper Miocene) } \\
\text { S. Gharib (Upper Miocene) } \\
\text { Belayim (Middle Miocene) * } \\
\text { Kareem (Middle Miocene) * } \\
\text { Rudeis (Lower Miocene) } \\
\text { Nukhul (Lower Miocene) } \\
\text { TOTAL } \\
\text { Average }\end{array}$ & $\begin{array}{cl} & <1 \\
& <1 \\
& <1 \\
11 & (10) \\
24 & (23) \\
14 & (20) \\
2 & (11) \\
& \\
51 & (64)\end{array}$ & $\begin{array}{l}25 \\
22 \\
22 \\
22 \\
22 \\
22 \\
16\end{array}$ & $\begin{array}{c}? \\
29 \\
775 \\
300(1000) \\
550(1125) \\
700(1450) \\
425(600) \\
\end{array}$ \\
\hline $\begin{array}{c}\text { PRE-RIFT } \\
\text { (pre-Oligocene) } \\
\text { Thebes (Eocene) } \\
\text { Sudr (Upper Cretaceous) } \\
\text { Nezzazat (Upper Cretaceous) } \\
\text { Nubia (Paleozoic - Lower Cretaceous) } \\
\text { Basement (pre-Phanerozoic) } \\
\text { TOTAL } \\
\text { Average }\end{array}$ & $\begin{array}{cc}<1 \quad(1) \\
<1 \\
19(14) \\
30(17) \\
<1 \quad(3) \\
49(36)\end{array}$ & $\begin{array}{l}19 \\
18 \\
18 \\
19 \\
10\end{array}$ & $\begin{array}{c}40 \\
? \\
150(200) \\
300(700) \\
400 \\
\\
200(500)\end{array}$ \\
\hline
\end{tabular}

* Approximate age equivalents of the Maqna reservoir rocks in the northern Red Sea. 
In contrast, Petroconsultants' data indicate as much as 30\% (3.5 BBOE) ultimate recoverable reserves could be in Nubia reservoirs, with average porosity of $19 \%$ and average permeability of 300 (geometric) or 700 (arithmetic) millidarcies (Table 2). The October field producing complex (36\% of all Nubia reserves) has a net-pay-to-grossthickness ratio of 0.2 for 700 meters ( $80 \%$ sandstone) with averages of $16 \%$ porosity, 236 millidarcies permeability, and $17 \%$ water saturation, and expected recovery of $45 \%$ (Lelek and others, 1992). Nubia pay cutoffs reported for Ramadan field (10\% of all Nubia reserves) are $11 \%$ porosity, 10 millidarcies permeability and $9 \%$ clay content (Abdine and others, 1992).

Other significant reservoirs in the Gulf of Suez are in mixed lithologies of the shallowmarine, pre-rift Upper Cretaceous Nezzazat Group (14-19\% of ultimate recoverable) and in composite syn-rift and post-rift Miocene strata (51-64\% of ultimate recoverable). Similar to Nubia, the Nezzazat Group is found throughout the Gulf of Suez. Reservoir quality averages $18 \%$ porosity and 150 (geometric) millidarcies permeability, with $10 \%$ of reserves in carbonates. Trapping configurations and reservoir capability of Nezzazat equivalents outside the Gulf of Suez are unknown, but age-equivalent sediments of continental to marine character probably were deposited over most of the Red Sea area (Schandelmeier and others, 1997).

Miocene reservoir rocks (Figure 2) were deposited in environments ranging from deep marine to deltaic, coastal, and subaerial. They are preserved everywhere within the Red Sea Basin Province except for the youngest axial areas of both the Red Sea rift and the Gulf of Aqaba. Areally and temporally, depositional conditions in the basins changed abruptly, resulting in a large variety of lithologies and facies. Major Miocene reservoirs from oldest to youngest are Rudeis (14-20\% of ultimate recoverable), Kareem (23-24\% of ultimate recoverable) and Belayim (10-11\% of ultimate recoverable).

Rudeis reservoirs are dominated by sandstone lithologies, and reservoir properties average $22 \%$ porosity and 700 millidarcies (geometric) permeability. Comparable values for the Kareem and Belayim formations are 22\% and 550 millidarcies and $22 \%$ and 300 millidarcies, respectively. The Kareem Formation is dominated by sandstone where productive, but one-third of Belayim reserves are in carbonates. Salah and Alsharhan (1997) report Kareem net-pay thickness to 195 meters, porosity from 9-33\%, and permeability from 20-730 millidarcies.

Syn- and post-rift Miocene reservoir rocks outside the Gulf of Suez have minimal published information about reservoir quality. Saudi Arabian productive Maqna (midMiocene) carbonates at Midyan field have 20\% porosity and 10 millidarcies permeability, and Sudanese Zeit-equivalent, productive (upper Miocene) dolomitic sandstones have $22 \%$ porosity and 29 millidarcies permeability (Petroconsultants, 1996).

\section{$\underline{\text { SEAL ROCK }}$}

The regional seal in the Red Sea Basin Province is a post-rift, upper Miocene, provincewide salt, evaporite and shale sequence recognized locally by the names Zeit, South 
Gharib, Dungunab, Amber and Mansiyah. This major marine evaporitic basin formed during times of reduced subsidence, when activation of the Aqaba transform fault caused Red Sea separation to become more oblique. Locally, these formations have associated sandstones and carbonates that have been successfully tested as reservoirs. The salt is generally thicker in the central part of the province and in graben centers. Within the Gulf of Suez, the most massive salt unit (South Gharib) averages 200 meters in thickness, generally thickening southward toward the Red Sea to a local maximum of 900 meters. Diapirism is exhibited in the southern Gulf of Suez and in the Red Sea, resulting in local absence of salt, in contrast to its presence in massive domes and walls of at least several thousand meters thick. Significant salt and evaporites can also be present in the underlying upper middle Miocene (Serravalian) formations (e.g., Belayim).

The regional upper Miocene salt seal is not present in the youngest axial areas of both the Red Sea rift and the Gulf of Aqaba.

Other lesser but effective seals on the producing-field scale exist in thinner evaporite units, shales, and massive impermeable carbonates of various thicknesses and most geologic ages.

\section{ASSESSMENT UNITS}

Three assessment units are delineated for the Sudr-Nubia(!) total petroleum system and two for the Maqna(!) petroleum system of the Red Sea Basin Province (Figures 3b and 3c). For the purposes of resource assessment, a field-growth function utilized by the U.S. Minerals Management Service for U.S. offshore areas was deemed the most appropriate of those available to use for determination of ultimate recoverable reserves in the province.

\section{Sudr-Nubia(!)}

In the Sudr-Nubia(!) total petroleum system (207101, Fig. 3b), largely confined to the Gulf of Suez and completely within Egypt, an "established" assessment unit (Gulf of Suez Block-Fault Fairway, 20710101) encompasses most known production, where trap styles, seals, and reservoirs have been previously described. It is approximately 15,000 sq $\mathrm{km}$ in area. All risk is negligible, and infrastructure is well established. In the future, field sizes will be smaller than those presently discovered, and traps will be subtler structures or combination structural-stratigraphic types. Many new fields (mostly oil) are expected to be discovered in the next 30 years, with grown field sizes ranging between 1 and 1000 MMBOE ultimate recoverable.

A second "hypothetical" assessment unit of < 2000-sq-km area (Gulf of Suez Qaa Plain, 20710102) exists onshore to the east of 20710101 and has good physical accessibility. Source, trap, and efficient migration routes are riskier than 20710101. A few oil fields with a possible maximum of $500 \mathrm{MMBOE}$, grown ultimate recoverable reserves, might be found in the next 30 years. 
A third "frontier" assessment unit with less established production than 20710101 (Southern Gulf of Suez, 20710103) at the deeper and hotter southern end of the Gulf of Suez and the northwestern Red Sea might additionally contain shallow salt-cored anticline traps and is likely to be more gas-prone than 20710101. It is nearly the same area as 20710101. Physical accessibility risk, due to greater water depths, is slightly increased from 20710101. Several dozen new fields are expected in the next 30 years with grown field sizes to a maximum of $600 \mathrm{MMBOE}$ ultimate recoverable.

\section{Maqna(!)}

The Maqna(!) total petroleum system (207102, Fig. 3c) includes all countries in the Red Sea Basin Province. It has one "frontier" assessment unit (Red Sea Coastal Block Faults, 20710201), more than 100,000 sq km in size, that includes all known production and contains block-faulted trapping configurations like those in the Gulf of Suez. This assessment unit includes coastal areas of the Red Sea and the southern Gulf of Suez overlapping Sudr-Nubia(!) assessment unit 20710103 and parts of Sudr-Nubia(!) assessment units 20710101 and 20710102. Twelve producing fields in the Gulf of Suez and all six reported fields in the Red Sea are attributed to Maqna(!) hydrocarbons. Dozens of new fields are expected to be discovered in the next 30 years with grown sizes (ultimate recoverable) ranging from one to several hundred MMBOE for oil fields and from six to several thousand BCF for gas fields.

A second Maqna(!) assessment unit (Red Sea Salt Basin, 20710202) is more seaward to the first, is nearly three times as large, and is "hypothetical" because it contains only hydrocarbon shows. It is characterized by significant salt thickness and tectonism, greater water depths (but less than 1000 meters), greater depth to basement, and higher thermal gradients. Gas and oil are expected in traps created by salt flowage. A greater geologic risk exists for this Maqna(!) assessment unit than for the coastal block-fault Maqna(!) assessment unit. Grown minimum field sizes here will likely be at least 10 MMBO and more than 60 BCF. Based on an analogue of U.S. Gulf Coast onshore salt basins, it is expected that several dozen new oil and gas fields will be discovered in the next 30 years with maximum grown sizes of approximately several hundred MMBOE for oil fields and more than 2 TCF for gas fields.

The boundary between the coastal block faults (20710201) and the salt basin (20710202) Maqna assessment units is based on Mitchell and others (1992) and Brown (1972).

\section{PROVINCE AREAS EVALUATED AS TOO HIGH RISK FOR ASSESSMENT PURPOSES}

The Gulf of Aqaba is considered too high risk to be quantitatively assessed in this effort because of its young age (<18 m.y.), low thermal gradient, significant water depth, and the unknown nature of possible source rocks, reservoir rocks and trapping configuration. But it is recognized that, approximately $200 \mathrm{~km}$ farther north along this transform system in the Dead Sea region, rapid subsidence of Cretaceous source rocks in the presence of 
low thermal gradients has generated recent hydrocarbons ( $<3 \mathrm{Ma}$, Lewan and others, 1997).

The axial Red Sea rift - defined by water depths greater than 1000 meters and/or the probable presence of new sea floor as evidenced by magnetic anomalies - is not quantitatively assessed in this effort because of its young age $(<5$ m.y.), high thermal gradient, concurrent volcanism, paucity of sedimentary section present, and improbability that Maqna-sourced hydrocarbons from the salt basins (20710202) migrated there and were trapped and preserved. It is possible that a hypothetical Pliocene total petroleum system with recent (<5 Ma) generation exists within this hot, axial portion of the Red Sea rift, but reservoir rock and trap presence are questionable. This axial rift area is approximately $25 \%$ of the total Red Sea area.

Jurassic-sourced petroleum systems in the northernmost Gulf of Suez and the southernmost Red Sea are of lesser volumetric potential than Sudr-Nubia(!) and Maqna(!) and are not addressed in this evaluation and assessment.

\section{SELECTED REFERENCES}

The Red Sea area has significant representation in international scientific literature, with volumes of study, often resulting from regional symposia, periodically published. Primary sources of published information include private and nationalized industry, academia, regional governmental agencies, the Deep Sea Drilling Project and the United Nations Development Program / World Bank.

Abdine, A.S., Meshref, W., Shahin, A.N., Garossino, P., and Shazly, S., 1992, Ramadan Field - Egypt, Gulf of Suez Basin, in Foster, N.H., and Beaumont, E.A., compilers, Treatise of petroleum geology, atlas of oil and gas fields, structural traps VI: Tulsa, OK, American Association of Petroleum Geologists, p. 113-139.

Alsharhan, A.S., and Salah, M.G., 1997a, A common source rock for Egyptian and Saudi hydrocarbons in the Red Sea: American Association of Petroleum Geologists Bulletin, v. 81, no. 10, p. 1640-1659.

Alsharhan, A.S., and Salah, M.G., 1997b, Lithostratigraphy, sedimentology and hydrocarbon habitat of the Pre-Cenomanian Nubian Sandstone in the Gulf of Suez oil province, Egypt: GeoArabia, v. 2, no. 4, p. 385-400.

Arab oil and gas directory, 1996: Paris, France, Arab Petroleum Research Center, $615 \mathrm{p}$.

Barakat, A.O., Mostafa, A., El-Gayar, M.S., and Rullkotter, J., 1997, Sourcedependent biomarker properties of five crude oils from the Gulf of Suez, Egypt: Organic Geochemistry, v. 26, no. 7/8, p. 441-450. 
Barnard, P.C., Thompson, S., Bastow, M.A., Ducreux, C., and Mathurin, G., 1992, Thermal maturity development and source-rock occurrence in the Red Sea and Gulf of Aden: Journal of Petroleum Geology, v. 15, no. 2, p. 173-186.

Bayer, H.-J., Hotzl, H., Jado, A.R., Roscher, B., and Voggenreiter, W., 1988, Sedimentary and structural evolution of the northwest Arabian Red Sea margin: Tectonphysics, v. 153, p. 137-151.

Beydoun, Z.R., 1989, The hydrocarbon prospects of the Red Sea - Gulf of Aden: a review: Journal of Petroleum Geology, v. 12, no. 2, p. 125-144.

Beydoun, Z.R., and Sikander, A.H., 1992, The Red Sea - Gulf of Aden: reassessment of hydrocarbon potential: Marine and Petroleum Geology, vol. 9, no. 5, p. 474-485.

Bohannon, R.G., and Eittreim, S.L., 1991, Tectonic development of passive continental margins of the southern and central Red Sea with a comparison to Wilkes Land, Antarctica: Tectonophysics, v. 198, no. 2-4, p. 129-154.

Bosworth, W., 1995, A high-strain rift model for the southern Gulf of Suez (Egypt), in Lambiase, J.J., ed., Hydrocarbon habitat in rift basins, Geological Society Special Publication No. 80: London, The Geological Society, p. 75-102.

Brown, G.F., compilor (U.S. Geological Survey), 1972, Tectonic map of the Arabian peninsula, 1:4,000,000, Arabian Peninsula Series map AP-2, prepared for the Saudi Arabian Ministry of Petroleum and Mineral Resources: Beirut, Lebanon, Middle East Export Press, Inc., printer.

Bunter, M.A.G., and Abdel Magid, A.E.M., 1989a, The Sudanese Red Sea: 1. New developments in stratigraphy and petroleum-geological evolution: Journal of Petroleum Geology, v. 12, no. 2, p. 145-166.

Bunter, M.A.G., and Abdel Magid, A.E.M., 1989b, The Sudanese Red Sea: 2. New developments in petroleum geochemistry: Journal of Petroleum Geology, v. 12, no. 2, p. 167-186.

Cole, G.A., Abu-Ali, M.A., Colling, E.L., Halpern, H.I., Carrigan, W.J., Savage, G.R., Scolaro, R.J., and Al-Sharidi, S.H., 1995, Petroleum geochemistry of the Midyan and Jaizan basins of the Red Sea, Saudi Arabia: Marine and Petroleum Geology, v. 12, no. 6, p. 597-614.

Coleman, R.G., 1993, Geologic evolution of the Red Sea: Oxford Monograph on Geology and Geophysics No. 24, New York, Oxford University Press, 186 p.

Colletta, B., Le Quellec, P., Letouzey, J., and Moretti, I., 1988, Longitudinal evolution of the Suez rift structure (Egypt): Tectonphysics, v. 153, p. 221-233. 
Crossley, R., Watkins, C., Raven, M., Cripps, D., Carnell, A., and Williams, D., 1992, The Sedimentary evolution of the Red Sea and Gulf of Aden: Journal of Petroleum Geology, v. 15, no. 2, p. 157-172.

Feinstein, S., Kohn, B.P., Steckler, M.S., and Eyal, M., 1996, Thermal history of the eastern margin of the Gulf of Suez, I. Reconstruction from borehole temperature and organic maturity measurements: Tectonophysics, v. 266, no. 1-4, p. 203-220.

Hughes, G.W., and Beydoun, Z.R., 1992, The Red Sea - Gulf of Aden: Biostratigraphy, lithostratigraphy and palaeoenvironments: Journal of Petroleum Geology, v. 15, no. 2, p. 135-156.

Hughes, G.W., and Filatoff, J., 1994, New biostratigraphic constraints on Saudi Arabian Red Sea pre- and syn-rift sequences, in Al-Husseini, M.I., ed., Middle East petroleum geosciences GEO’94, vol. II: Bahrain, Gulf Petrolink, p. 517-528.

Klett, T.R., Ahlbrandt, T.S., Schmoker, J.W., and Dolton, G.L., 1997, Ranking of the world's oil and gas provinces by known petroleum volumes: U.S. Geological Survey Open File Report 97-463, CD Rom.

Knott, S.D., Beach, A., Welbon, A.I., and Brockbank, P.J., 1995, Basin inversion in the Gulf of Suez: implications for exploration and development in failed rifts, in Buchanon, J.G., and Buchanan, P.G., eds., Basin inversion, The Geological Society Special Publication No. 88: London, The Geological Society, p. 59-81 .

Lelek, J.J., Shepherd, D.B., Stone, D.M., and Abdine, A.S., 1992, October Field, the latest giant under development in Egypt's Gulf of Suez, in Halbouty, M.T., ed., Giant oil and gas fields of the decade 1978-1988: Tulsa, OK, American Association of Petroleum Geologists Memoir 54, p. 231-249.

Lewan, M.D., Ramini, H., and Tannenbaum, E., 1997, Petroleum formation in Senonian carbonate source rocks of the Dead Sea Basin (abs): Rocky Mountain Association of Geologists Outcrop, September, 1997, p. 15-16.

Magoon, L.B., and Dow, W.G., 1994, The petroleum system, in Magoon, L.B., and Dow, W.G., eds., The Petroleum System - from Source to Trap: A.A.P.G. Memoir 60 , p. 3-23.

Makris, J., and Henke, C. H., 1992, Pull-apart evolution of the Red Sea: Journal of Petroleum Geology, v. 15, no. 2, p. 127-134

Makris, J., Henke, C.H., Egloff, F., and Akamaluk, T., 1991, The gravity field of the Red Sea and East Africa: Tectonophysics, v. 198, p. 369-381. 
Makris, J., and Rihm, R., 1991, Shear-controlled evolution of the Red Sea: pull apart model: Tectonophysics, V. 198, no. 2-4, p. 441-466.

Makris, J., Tsironidis, J., and Richter, H., 1991, Heatflow density distribution in the Red Sea: Tectonophysics, v. 198, no. 2-4, p. 383-393.

Magoon, L.B., and Dow, W.G., 1994, The petroleum system, in Magoon, L.B., and Dow, W.G., eds., The petroleum system - from source to trap: Tulsa, OK, American Association of Petroleum Geologists Memoir 60, p. 3-24.

Mitchell, D.J.W., Allen, R.B., Salama, W., and Abouzakm, A., 1992, Tectonostratigraphic framework and hydrocarbon potential of the Red Sea: Journal of Petroleum Geology, v. 15, no. 2, p. 187-210.

Oil and Gas Journal, 1994 (July 11), Saudi production capacity climbing to 10 million b/d, p. 44-47.

Patton, T.L., Moustafa, A.R., Nelson, R.A., and Abdine, S.A., 1994, Tectonic evolution and structural setting of the Suez Rift, in Landon, S.M., ed., Interior rift basins: Tulsa, OK, American Association of Petroleum Geologists Memoir 59, p. 9-55.

Petroconsultants, 1996, Petroleum exploration and production database: Houston, Texas, Petroconsultants, Inc., [database available from Petroconsultants, Inc., P.O. Box 740619, Houston, TX, 77242-0619].

Petroconsultants, 1989, Rift systems, hydrocarbon habitat and potential of riftrelated basins: Dublin, Ireland, Petroconsultants, Inc.

Richardson, M. and Arthur, M.A., 1988, The Gulf of Suez - northern Red Sea Neogene rift: a quantitive basin analysis: Marine and Petroleum Geology, v. 5, no. 3, p. 247-270.

Rohrback, B.G., 1983, Crude oil geochemistry of the Gulf of Suez, in Bjoroey, M., Albrecht, C., Cornford, C., de Groot, K., Eglinton, G., Galimov, E., Leythaeuser, D., Pelet, R., Rullkoetter, J., and Speers, G., eds., Advances in Organic Geochemistry, 1981, Proceedings of the International Meeting on Organic Geochemistry: New York, Wiley and Sons, p. 39-48.

Salah, M.G., and Alsharhan, A.S., 1997, The Miocene Kareem Formation in the southern Gulf of Suez, Egypt: a review of stratigraphy and petroleum geology: Journal of Petroleum Geology, v. 20, no. 3, p. 327-346.

Salah, M.G., and Alsharhan, A.S., 1996, Structural influence on hydrocarbon entrapment in the northwestern Red Sea, Egypt: American Association of Petroleum Geologists Bulletin, v. 80, no. 1, p. 101-118. 
Savoyat, E., Shiferaw, A., and Balcha, T., 1989, Petroleum exploration in the Ethiopian Red Sea: Journal of Petroleum Geology, v. 12, no. 2, p. 187-204.

Schandelmeier, H., and Reynolds, P.-O., eds., and Semtner, A.-K., co-editor of plates, 1997, Palaeogeographic-palaeotectonic atlas of north-eastern Africa, Arabia, and adjacent areas: Rotterdam, Netherlands, A.A. Balkema, 160 p., 17 plates.

Schutz, K.I., 1994, Structure and stratigraphy of the Gulf of Suez, Egypt, in Landon, S.M., ed., Interior rift basins: Tulsa, OK, American Association of Petroleum Geologists Memoir 59, p. 57-96.

Shahin, A.N., 1988, Oil window in the Gulf of Suez, Egypt (abs): Amercian Association of Petroleum Geologists Bulletin, v. 72, n.8, p. 1024-1025.

Shahin, A.N., 1997, Petroleum systems in the northern Gulf of Suez, Egypt (abs): American Association of Petroleum Geologists Bulletin, v. 81, no. 8, p. 1411.

Wescott, W.A., Krebs, W.N., Dolson, J.C., Karamat, S.A., and Nummedal, D., 1996, Rift basin sequence stratigraphy: some examples from the Gulf of Suez: GeoArabia, Middle East Petroleum Geosciences, vol. 1, no. 2, p. 343-357. 